\title{
Controls on basal Zechstein (Wuchiapingian) evaporite deposition in SW Poland
}

\author{
Kazimierz DYJACZYŃSKI ${ }^{1}$ and Tadeusz Marek PERYT ${ }^{2, *}$ * \\ 1 Polish Oil and Gas Company, Bohaterów Westerplatte 15, 65-034 Zielona Góra, Poland \\ 2 Polish Geological Institute - National Research Institute, Rakowiecka 4, 00-975 Warszawa, Poland
}

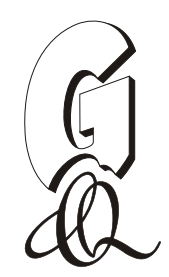

Dyjaczyński, K., Peryt, T.M., 2014. Controls on basal Zechstein (Wuchiapingian) evaporite deposition in SW Poland. Geological Quarterly, 58 (3): 485-502, doi: 10.7306/gq.1166

\begin{abstract}
The development of basal Zechstein (Wuchiapingian) strata in SW Poland indicates the existence of a varied relief inherited after the flooding of the pre-existing depression by the transgressing Zechstein sea. The deeper parts of the basin were the place of development of thin basinal Zechstein Limestone showing sedimentary condensation manifested by bored and encrusted grains and thick evaporites (mostly halite). In shallow parts, Zechstein Limestone reefs followed by thinner evaporite sequences (dominated by anhydrite) were formed. The analysis of 2D sections extracted from 3D seismic data showed that instead of three conventionally recognized evaporitic units in the PZ1 cycle, five units occur (from the base to the top: Lower Anhydrite, Lower Oldest Halite, Middle Anhydrite, Upper OIdest Halite, Upper Anhydrite). In any particular place their number may vary from two (Lower Anhydrite at the base of the PZ1 cycle and Upper Anhydrite at the top of the PZ1 cycle) to five. Two units of Lower Anhydrite occur throughout the platform and basinal zones, showing a deepening-upwards (transgressive) trend. Halite sedimentation, in the deepest parts of salt basins, began shortly after the deposition of the upper Lower Anhydrite while on sulphate platform areas, sulphate deposition continued. The Lower Oldest Halite deposits occur in the depressions. Between the halite basins, anhydrite platforms occur, and the thickness of anhydrite platform deposits is smaller than is observed in salt basins. The Upper Oldest Halite in turn is recorded above the anhydrite platform. The two halite units represent different phases of development of halite basins. Formation of the Lower Oldest Halite basins was related to pre-Zechstein depressions, although in some cases their syndepositional subsidence was controlled by reactivation of former faults within the sub-Zechstein basement. In turn, the Upper Oldest Halite basins used the accommodation space created due to anhydritization of the Lower Anhydrite deposits, that were composed originally of selenitic gypsum, and the associated volume loss. 3D seismic data, constrained by borehole data, show that the PZ1 evaporites in SW Poland were deposited in a far more complex and dynamic system than previously assumed.
\end{abstract}

Key words: Zechstein Basin, evaporites, 3D seismics, lithofacies, sedimentation, anhydritization.

\section{INTRODUCTION}

Environmental conditions of large-scale evaporite precipitation, as characteristic of the Lopingian Zechstein basin of NW and Central Europe (Fig. 1A), have been discussed by Sonnenfeld (1984) who summarized the basic prerequisites. One of the most crucial conditions is that a gentle depression must pre-exist to initiate brine concentration (Sonnenfeld, 1984). The existence of a varied relief inherited after the flooding of the pre-existing depression by the transgressing Zechstein sea at some $258 \mathrm{Ma}$ (see Peryt et al., 2012a with references therein) is indicated by the development of basal Zechstein strata in SW Poland (D. Peryt et al., 2012; Fig. 1). During the deposition of the Zechstein Limestone the deeper parts of the basin were the place of development of thin basinal facies and in shallow parts (e.g., uplifted tectonic blocks locally forming islands) carbonate

\footnotetext{
* Corresponding author: e-mail: tadeusz.peryt@pgi.gov.pl
}

Received: September 9, 2013; accepted: March 4, 2014; first published online: April 17, 2014 buildups (reefs) formed (Kiersnowski et al., 2010). The Kupferschiefer is lacking over the elevations of the Zechstein substrate, mostly built of Carboniferous and/or Permian volcanic rocks, where the Zechstein Limestone reefs developed. In turn, in the depressions the Kupferschiefer commonly occurs. Subsequently, thin PZ1 evaporites were deposited in the reef locations while much thicker evaporites accumulated in the former depressions. Those observations suggest that the area of SW Poland can serve as a classic example of the filling of antecedent topography by halite. If the subsidence during the deposition of the PZ1 evaporites is ignored, then the differences between the reef elevations and adjacent basins could have exceeded $100 \mathrm{~m}$ in places at the onset of Zechstein deposition (see Kiersnowski et al., 2010: fig. 6). However, Rockel and Ziegenhardt (1979) showed that south of Berlin the Oldest Halite precipitated on downthrown fault blocks, and their conclusion was supported by subsequent reports from various parts of Germany and the Netherlands (see references in Underhill and Hunter, 2008). Accordingly, the actual relief during the deposition of the lowest Zechstein strata in western Poland may have been smaller.

In this paper we discuss the relationship between the sulphate and chloride facies in the south and west of Grodzisk Wlkp. (Figs. 1B and 2) which is one of the best known areas in 

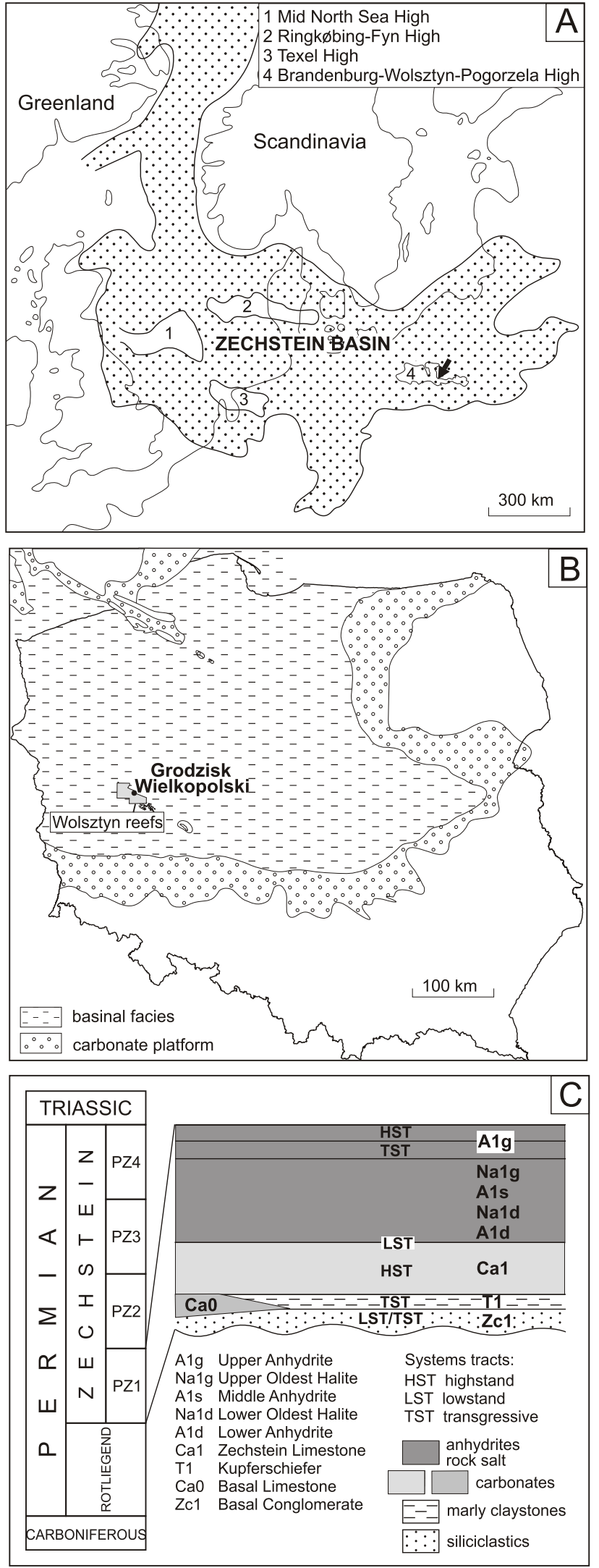

Fig. 1A - Zechstein basin showing the location of the Brandenburg-Wolsztyn-Pogorzela High (after Kiersnowski et al., 2010; arrow shows location of Grodzisk WIkp.); B - basin facies of the Zechstein Limestone in Poland showing the area studied (grey polygon corresponding to Figure 2); C - stratigraphy of the basal Zechstein (after Wagner and Peryt, 1997, with some changes resulting from the current study) the Fore-Sudetic Monocline (SW Poland) in terms of available information from deep borehole and seismic data, both 2D as well as 3D.

\section{GEOLOGICAL SETTING}

During the Permian, the area of western Poland belonged to the Southern Permian Basin, which was formed in the Late Carboniferous to Early Permian as a result of subsidence caused by rifting (Gast, 1988; Pharaoh et al., 2010). The beginning of these extensional movements created a complex, multidirectional system of horsts and grabens (Ziegler, 1990). One of the intra-basin horsts is the Brandenburg-Wolsztyn-Pogorzela High (WPH) that separated the Zielona Góra Basin from the Variscan Foreland (Polish Basin) (Kiersnowski et al., 2010). The WPH has a complex geological history and structural framework, and its structural segmentation suggests that the WPH is an uplifted element of a possible post-Variscan broad, mega-dextral strike-slip zone trending NW-SE with a series of pull-apart basins located oblique to the general regional tectonic framework (see Kiersnowski et al., 2010, for detailed discussion). Kiersnowski et al. (2010) documented a tectonic differentiation of particular tectonic blocks of the WPH and a rapid, strong tectonic rejuvenation during latest Rotliegend and Early Zechstein times, accompanied by varied tectonic subsidence during the Zechstein; however, by the beginning of the PZ2 cycle, tectonic activity was weak or even absent in the area studied (Kiersnowski et al., 2010). As the Zechstein flooding was rapid (Smith, 1979), the Rotliegend landscape was practically untouched or, as described by D. Peryt et al. (2012), only slightly changed by processes accompanying the transgression.

In the major part of the study area (Fig. 2), outside the reef area, related to the Wolsztyn High that was characterized by Dyjaczynski et al. (2001), Kiersnowski et al. (2010) and Peryt et al. (2012b) , Ca1 is thin and its thickness usually ranges between $0.5-3.0 \mathrm{~m}$. It mostly shows a wackestone-packstone texture (Peryt et al., 2014). The PZ1 evaporites which follow are ca. 140-ca. $215 \mathrm{~m}$ thick. Characteristic sections of the PZ1 evaporites are shown in Figure 3. A1d is a lowstand deposit with respect to sea level outside the isolated basin (Wagner and Peryt, 1997), but it is a highstand systems tract with respect to the subsequent drawdown hydrogeology (cf. Warren, 1999). Wagner and Peryt (1997) regarded Na1 as a LST, but Peryt (2010) indicated that in the central part of the basin Na1 should be regarded as a TST (cf. Kendall, 2010). Strohmenger et al. (1996) concluded that on the evaporite platform Na1 is HST. BrA1g is regarded as a TST, and the rest of the A1g section as a HST (Fig. 1C; Peryt et al., 1996).

The study area is located within the marginal evaporite platform that was wide in the southern margin of the Zechstein PZ1 (Werra) basin (e.g., Richter-Bernburg, 1985; Peryt et al., 2010a). In western Poland, the PZ1 deposits are mostly $>200$ m thick over much of the evaporite platform area; thinner ( $<200 \mathrm{~m}$ thick) sequences are related to the Wolsztyn High. The Oldest Halite (Na1) basin, stretching NW-SE and located just beyond the northeastern margin of the Wolsztyn High, is ca. $35 \mathrm{~km}$ long and $1-6 \mathrm{~km}$ wide. This basin is surrounded by Lower Anhydrite (A1d) platforms within which local, smaller halite basins developed, in particular at the northern side of the main basin. In the halite basins, and especially in the main basin, the thickness of Na1 reaches about $120 \mathrm{~m}$ while that of $\mathrm{A} 1 \mathrm{~d}$ is about $10-20 \mathrm{~m}$. The PZ1 deposits are covered by the younger Zechstein cycles (PZ2-PZ4, usually 260-280 m thick), followed by up to $1650 \mathrm{~m}$ 


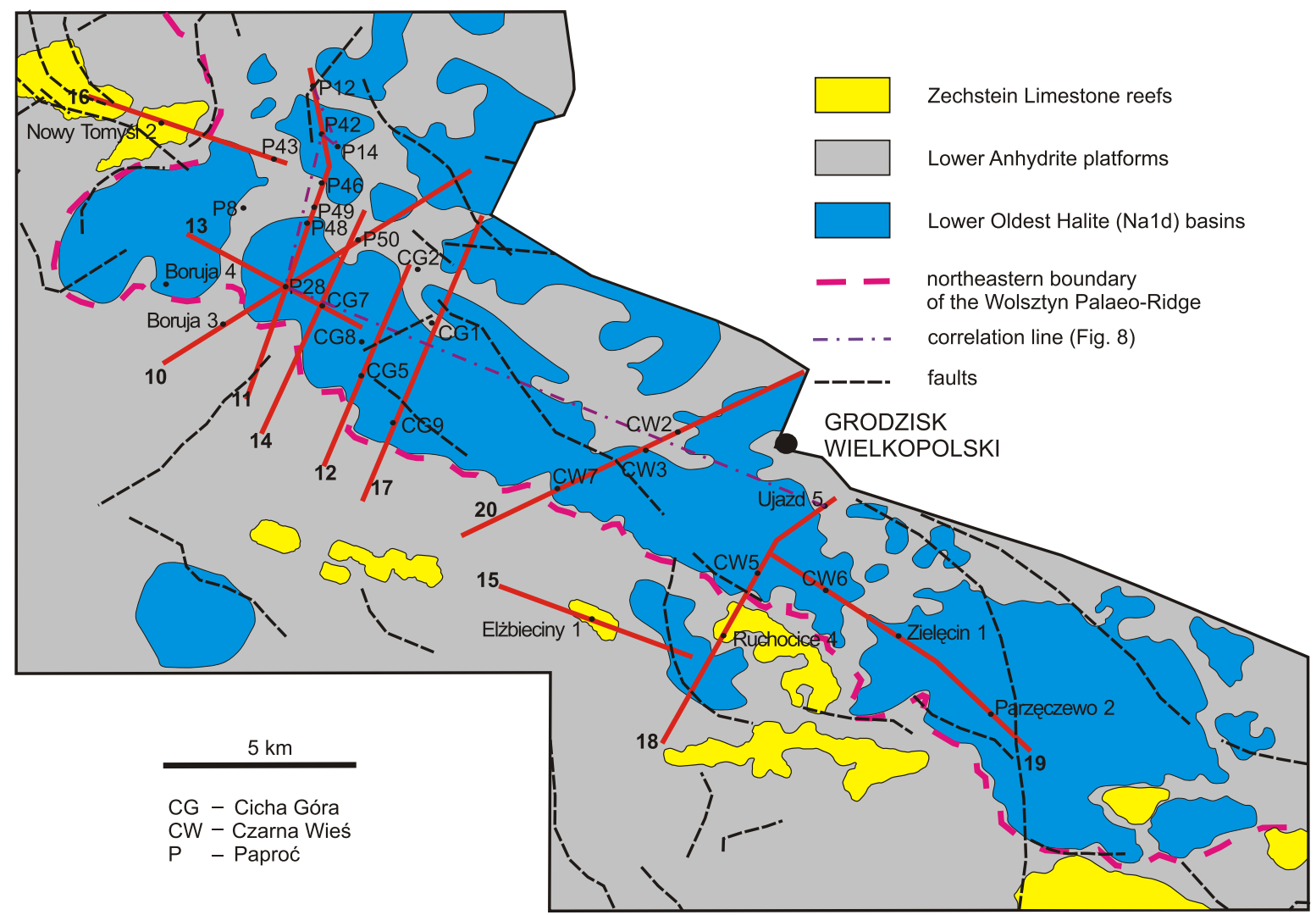

Fig. 2. Lower Oldest Halite basins in the south and west of Grodzisk WIkp., showing the locations of seismic sections (solid red lines; Figs. 10-20) (after K. Dyjaczyński and K. Kucharczyk, 2008, unpublished) and faults cutting the boundary of the Zechstein with the older strata (after Kiersnowski et al., 2010, updated by H. Kiersnowski)

Boruja 3

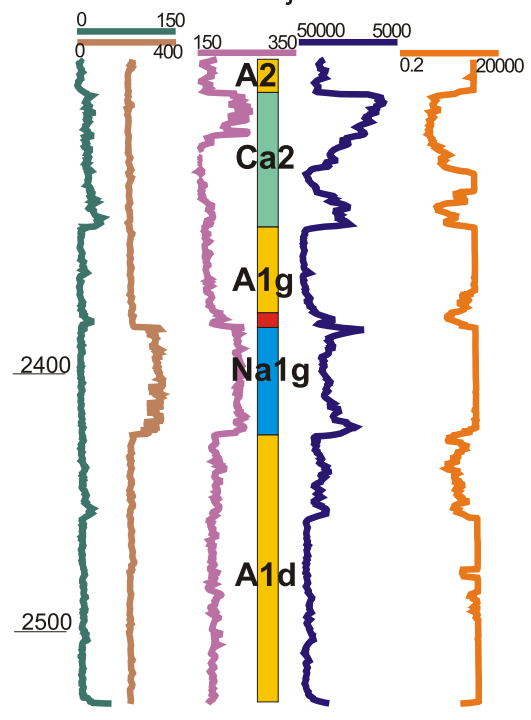

Paproć 28

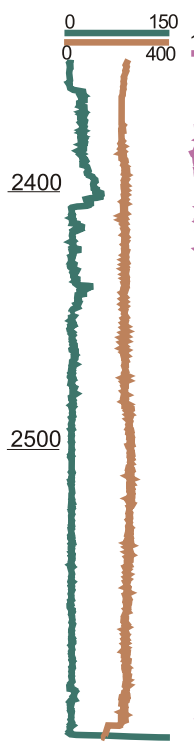

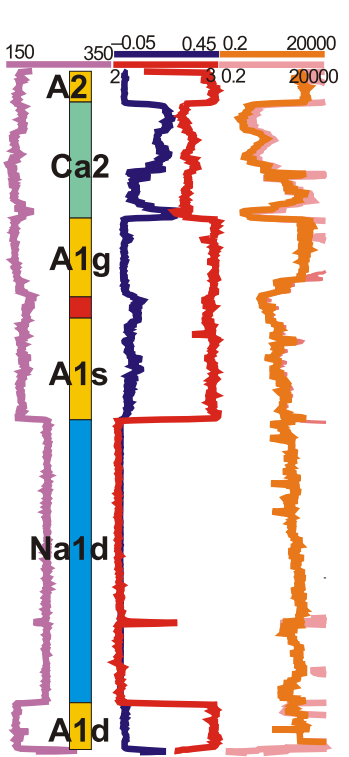

Cicha Góra 5
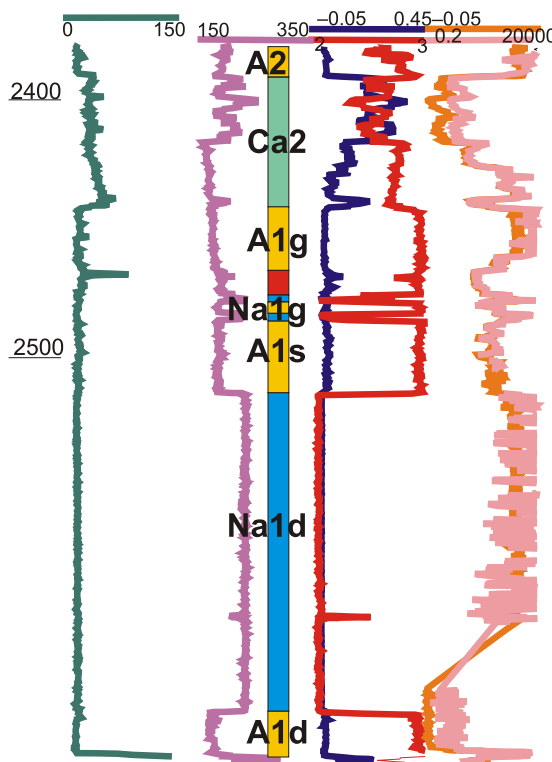

Anhydrite Breccia (BrA1g)

Fig. 3. Lower Anhydrite-Main Dolomite interval in the Boruja 3, Paproć 28 and Cicha Góra 5 boreholes (for explanation of abbreviations of stratigraphical units see Fig. 1C) 
thick of Triassic, up to $437 \mathrm{~m}$ of Jurassic and locally recorded Cretaceous deposits up to $229 \mathrm{~m}$ thick, which are in turn covered by thin Cenozoic deposits (Kotarba et al., 2006).

\section{METHODOLOGY}

The basis of the paper is a seismo-stratigraphic analysis of basal Zechstein strata along selected $2 \mathrm{D}$ lines extracted from a 3D seismic volume, calibrated by well data, in particular by results of sedimentological and geophysical logging data of basal Zechstein strata in boreholes located within the study area (Fig. 3 ). The basis of stratigraphic subdivision of evaporite strata of the PZ1 cycle was the location, in the section, of the characteristic marker unit - the Anhydrite Breccia (BrA1g), that occurs throughout the entire Polish Zechstein basin at the base of the Upper Anhydrite (A1g) (e.g., Tomaszewski, 1962; Kłapciński, 1966; Podemski, 1973; Lorenc, 1975; Wagner et al., 1978; Wagner, 1994; Peryt et al., 1996). It is easily distinguishable in particular boreholes based on geophysical logging data (see Fig. 3). The breccia is the transgressive systems tract deposit although the material composing it was a lag deposit of the preceding exposure period (Peryt et al., 1996).

The vertical resolution of the seismic data is $20 \mathrm{~m}$. The locations of the seismic sections and boreholes discussed in this paper are shown in Figure 2; the actual number of sections studied was considerably greater and they were used for mapping the outline of the main salt basin and satellite basins. All the data was acquired by Geofizyka Torun on behalf of the Polish Oil and Gas Company, although for the purpose of this paper many modifications have been made. In many places the interpretation of those sections, as far as the PZ1 evaporites are concerned, was modified after the interpretation done at Geofizyka Toruń; in 1995, salt basins had already been mapped by A. Klecan (unpublished) based on 2D seismic data.

The interpretation of seismic data followed the approach discussed by Antonowicz and Knieszner (1984) and Górski et al. (2000) of correlation of five reflectors related to the boundaries of rocks with high acoustic impendence and rocks with lower acoustic impendence: $Z_{4}$ (bottom of $A 4$ or bottom of $\mathrm{Na} 4 /$ top of $A 4$ ), $Z_{3}$ (bottom of Na3/top of $A 3$ ), $Z_{2}$ (bottom of Na2/top of A2), $Z_{1}$ (bottom of Na1/top of A1d) and $Z_{1}$, (bottom of A1d or bottom of Ca1/top of T1 or of the Zechstein substrate) (cf. Figs. 10-20).

The cores available in the study area included the Zechstein Limestone and the lower part of the Lower Anhydrite and they were subject to standard sedimentological and microfacies analysis aimed at providing an additional information on the geological background of the onset of evaporite deposition. A collection of 48 thin sections, made from the Zechstein Limestone rocks by the Zielona Góra Branch of the Polish Oil and Gas Company and the PGI-NRI, was analysed using standard petrological methods in this study; the thin sections came from the Boruja 3, 4, Cicha Góra 2, 4, 5, 6, 9, and Czarna Wieś 2, 5, 6 boreholes. Results of the study of two Zechstein Limestone sections located in the study area (Czarna Wieś 4 and Paproć 28) have recently been published by Peryt et al. (2014).

\section{RESULTS AND INTERPRETATION}

\section{PETROLOGY OF THE ZECHSTEIN LIMESTONE}

The Zechstein sequence in the study area starts with thin, usually $<1 \mathrm{~m}$ thick carbonate rocks of variable mineralogy. In some boreholes (e.g., Paproć 28 - see Peryt et al., 2014: fig. 4, and Cicha Góra 5 - Fig. 4) the carbonate rocks are underlain by $\mathrm{T} 1 \mathrm{up}$ to $0.7 \mathrm{~m}$ thick. Below it thin $\mathrm{Ca0}$ (usually bioclastic wackestones-packstones) occurs occasionally (e.g., Figs. 4 and 5J; Peryt et al., 2014: fig. 4). In its uppermost part in the Cicha Góra 5 borehole abundant, probably monospecific ostracods occur (Fig. 4E) that indicate an extreme, most likely brackish environment characterized by conditions very different from those which prevailed earlier. The T1 deposits show microfacies typical of this unit (see Oszczepalski and Rydzewski, 1987). When those two units are lacking (e.g., Czarna Wieś 6), bioclastic wackestones-packstones of Ca1 overlie the Rotliegend siliciclastic deposits (Fig. 5G, H).

The Ca1 deposits consist mostly of peloid and bioclastic wackestones and packstones with foraminifers (uniserial, "spiral", Earlandia, encrusting), bivalves, ostracods, gastropods, and a few brachiopods, bryozoans and corals (Figs. 4B-D, 5A-E and 6; Peryt et al., 2014). In addition, peloid-oncoid (occasionally bioclastic) packstones, recystallised oncoid packstones (Peryt et al., 2014) and other microbially-mediated carbonates occur (Figs. 4F and $5 \mathrm{C}-\mathrm{E}$ ). The $\mathrm{Ca} 1$ sections in the study area are typically much thinner $(<1 \mathrm{~m})$ than is usual in basinal sections; they show many facies criteria for deep-marine carbonates (see Flügel, 1982: table 53) and were called "condensed sequences" by Peryt and Ważny (1980). The condensation reflects different factors (Flügel, 2010) of which a decrease in the accumulation rate (sedimentary condensation) was important for $\mathrm{Ca} 1$.

Although many condensed sections exhibit a three-stage sequence including a reduced sedimentation stage, an omission stage, and an Fe and Fe/Mn crust stage (Flügel, 2010), only the first stage was recorded so far for the study area. The manifestation of the reduced sedimentation stage is bored and encrusted grains (Fig. 4B; Peryt et al., 2014: figs. 5-7); other common manifestations such as shell concentrations and reworked iron crusts are lacking.

\section{DEVELOPMENT OF THE LOWER ANHYDRITE}

The boundary between Ca1 and A1d is abrupt (Fig. 4A). In many cases the A1d sections show a nodular development (Figs. 7 and 8) although clear pseudomorphs after selenite crystals can be observed in the sections from the reef area (Fig. 7). This strongly suggests that at least some nodular anhydrites originated in a shallow subaqueous environment characterized by concentrated brines as has been recorded in modern marine selenite facies: coastal salt works - evaporative salinas (e.g., Ortí Cabo et al., 1984) and in some natural coastal lakes (e.g., Warren, 1982). Ancient occurrences of selenite facies cover a wide range of settings that require specific environmental configurations, and in particular, the existence of an outflow of heavy brines as well as the accumulation of chlorides on the platforms and in the basins (see Ortí, 2010).

In the core from Kościan 21 borehole, nodular anhydrite with dolomite streaks occurs in the lower part of $A 1 d$, which is followed by recrystallised bedded anhydrite and, in the upper part, by bedded nodular anhydrite with streaks of dolomite and rare clay-rich interbeds (Peryt et al., 2010b). A geological-geophysical correlation of the two lowest units of A1d from the platform and basinal zones is shown in Figure 8 . The lower $A$ unit is composed of nodular anhydrite that is characterized by low gamma values and very high resistivity. The higher B unit shows anhydrite with carbonate laminae, often of supposed microbial nature, with common manifestations of hydrocarbons; due to an increased clay minerals content that accompanies the 

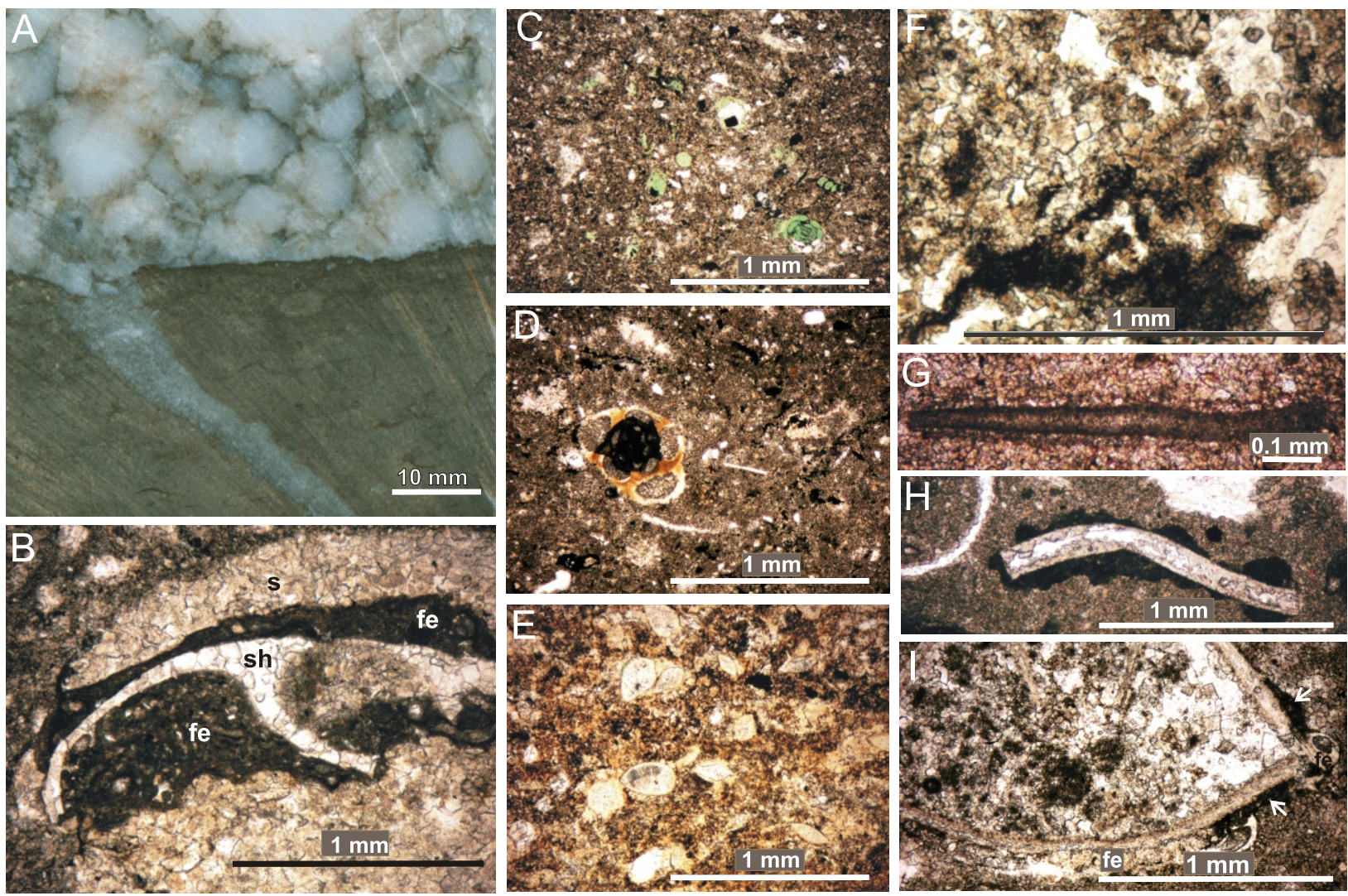

Fig. 4. Microfacies of the Cicha Góra 5 (A-E) and Boruja 3 (F-I) sections; A - Zechstein Limestone-Lower Anhydrite boundary; B, C, F-I - Zechstein Limestone; D - above the Kupferschiefer-Zechstein Limestone boundary, E - Kupferschiefer

A - nodular anhydrite overlying recrystallised oncolitic packstone (depth 2653.94-2654.0 m); B - recrystallised oncolite (on) with sparitic portions (s) containing shells (sh) with foraminiferal encrustations (fe) (depth 2653.98 m); C - peloidal-bioclastic wackestone-packstone with foraminifera (often filled by glauconite and more rare pyrite; depth $2654.85 \mathrm{~m}$ ); $\mathbf{D}-$ bioclastic-peloidal wackestone with minute quartz grains, common thin shells and foraminifera (left centre; depth 2655.03 m); $\mathbf{E}-$ microsparite with ostracods (depth 2655.7 m); F - recrystallised microbial dolomite (depth $2526.1 \mathrm{~m}$ ); G - Earlandia sp. (depth 2526.3 m); H - shell pseudomorph with foraminiferal encrustation (depth $2526.5 \mathrm{~m}$ ); I - recrystallised dolomite with bioclasts - shell filled by peloids, with microbial (arrows) and foraminiferal (fe) encrustations (depth $2526.7 \mathrm{~m}$ )

higher carbonate content the unit is characterized by increased GR values and decreased resistivity. It is uppermost unit in the A1d basin sections (e.g., in Paproć 42 and Paproć 28) and thus it is supposed that halite sedimentation in the deepest parts of the salt basins began shortly after the deposition of the B unit, whereas on the A1d platform area sulphate deposition still continued (cf. Fig. 22).

\section{INTERPRETATION OF SEISMIC DATA}

The seismic section along the Boruja 3-Paproć 28-Paproć 50 line (Fig. 9) shows the approach applied in this paper. As a reference level the flat top of $\mathrm{Na} 4$ was chosen. If seismic data were not available borehole data-based sections should look like those shown in Figure 9A, B. Figure 9A represents an interpretation that applies if only the major lithologies are concerned, whereas in Figure 9 the base of $\mathrm{A} 1 \mathrm{~g}$ in the Paproć 28 borehole is put at the base of BrA1g. However, if we consider the available seismic section passing through all three sections (Fig. 10 ), the geological cross-section shown in Figure $9 \mathrm{C}$ is most likely.

Because of its negligible thickness the Zechstein Limestone is not shown in Figure 9 as well as in many seismic sec- tions shown in Figures 10-20, except for reef locations (Figs. 15 and 16$)$.

The cross-section along the Boruja 3-Paproć 28-Paproć 50 line (Fig. 9) shows that there are more evaporite units of stratigraphic potential within the Z1 cycle than the three conventionally recognized, i.e. A1d, Na1 and A1g (Fig. 1). Instead of those three units, five units occur in the area studied, although their number may vary from two to five in particular places (e.g., in a borehole). Two of these, the Lower Anhydrite (A1d) at the base of the PZ1 cycle and Upper Anhydrite $(A 1 \mathrm{~g})$ at the top of the PZ1 cycle occur in every location. A1g is delimited by BrA1g at its base and the Main Dolomite (Ca2) at its top, and hence it is very well constrained.

In addition to those two anhydrite units, two halite units: the Lower Oldest Halite (Na1d) and the Upper Oldest Halite (Na1g) occur, separated by the Middle Anhydrite (A1s). The BrA1g lies upon the Upper Oldest Halite (Na1g) or Middle Anhydrite (A1s) (Figs. 3 and 9); the A1s is distinguished only in the case where anhydrite strata occurring above Na1d are overlain by BrA1g, and thus in some cases it is clearly coeval with the upper part of A1d. It may also overlie the Lower Anhydrite (e.g., Fig. 18).

The interpretation of seismic sections (with the reference level being either the $\mathrm{Na} 4$ top or the top of the Middle Buntsandstein Tp2; Figs. 10-20) demonstrate the complex re- 


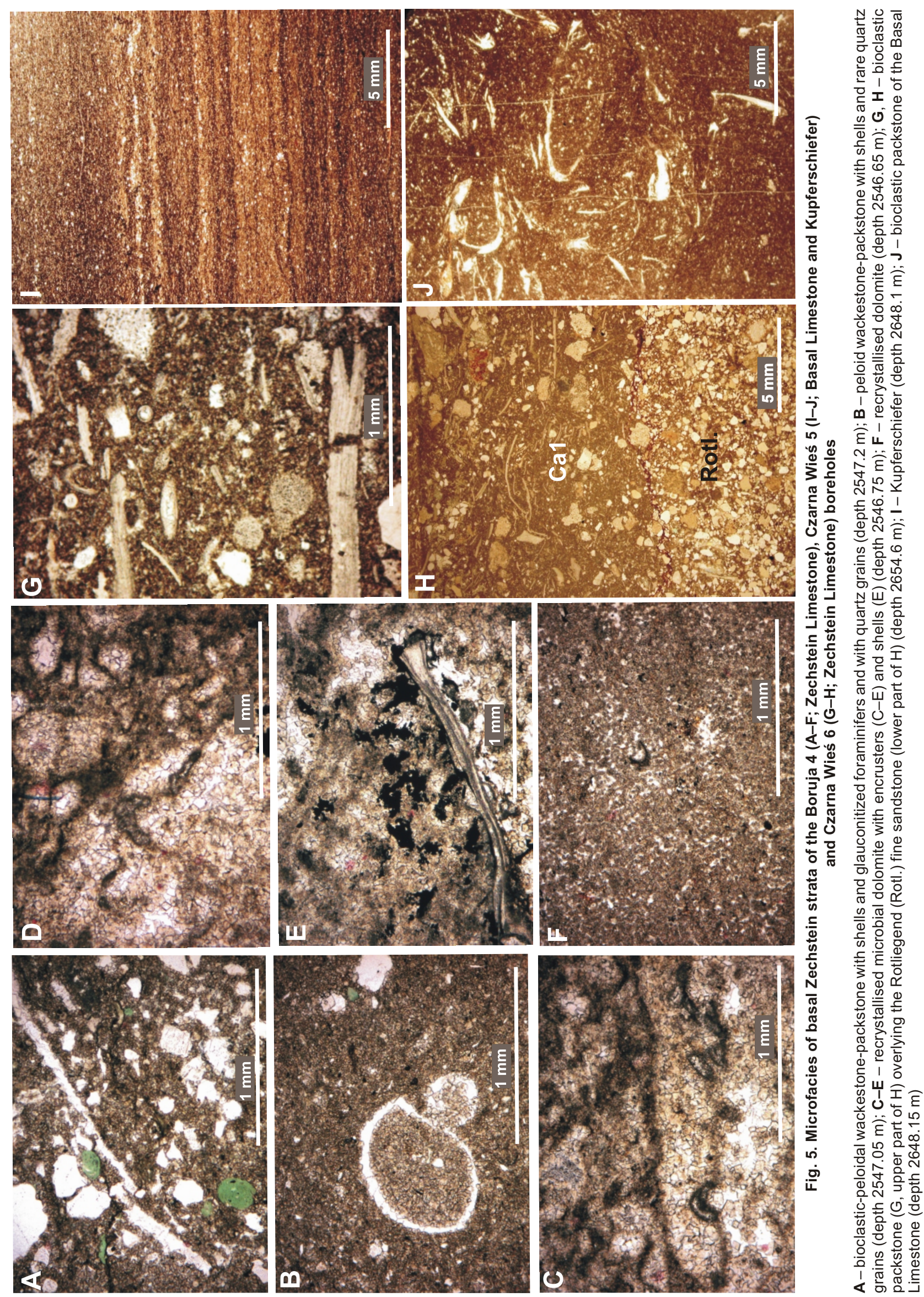




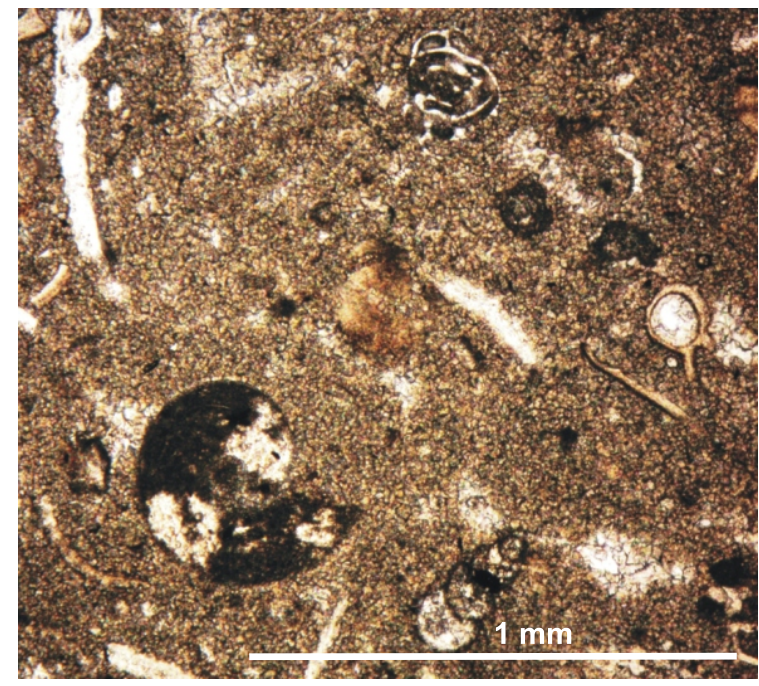

Fig. 6. Dolomite - bioclastic wackestone with foraminifers (uniserial, hemigordiopsid, encrusting), shells (gastropods, bivalves, ostracods)

Boruja 3 (depth $2526.9 \mathrm{~m}$ ) lations of the basal Zechstein strata within the study area. The seismic data show that the $\mathrm{Na} 1 \mathrm{~d}$ deposits are related to the depressions (Figs. 12-14 and 17-20). The A1d platforms are located between the Na1d basins, and as the rule their occurrence coincides with the presence of elevated areas during the onset of A1d deposition. The thickness of the Na1d basin deposits is greater than the thickness of the $\mathrm{A} 1 \mathrm{~d}$ platform deposits (Figs. 10, 11, 13, 14 and 17-19) as generally for other areas of the Zechstein Basin (e.g., Peryt, 1994) owing to deposition of halite deposits in the depocentres (Richter-Bernburg, 1955). $\mathrm{Na1g}$ in turn is recorded above the A1d platforms and commonly it does not occur within the central parts of the Na1d basin area (Fig. 21). Accordingly, its distribution indicates a shift of depocentres at that time, the reason for which will be discussed below. Usually, Na1g pinches out towards the central part of Na1d bodies (Figs. 10, 11, 13, 14, 17, 19 and 20). The thickness of the Na1d unit is greater than that of Na1g. In the study area the area of $\mathrm{Na} 1 \mathrm{~g}$ deposition is greater than the area of Na1d occurrence (Fig. 21). In the Czarna Wies 7 borehole the thickness of $\mathrm{Na1g}$ is relatively large $(51 \mathrm{~m})$ and the halite unit contains numerous anhydrite intercalations.

The interpretation of seismic depth sections passing through a relatively thin Ca1 reef recorded in the Elżbieciny 1 borehole (12 $\mathrm{m}$ ) shows the occurrence of $\mathrm{Na} 1 \mathrm{~g}$ and a part of the

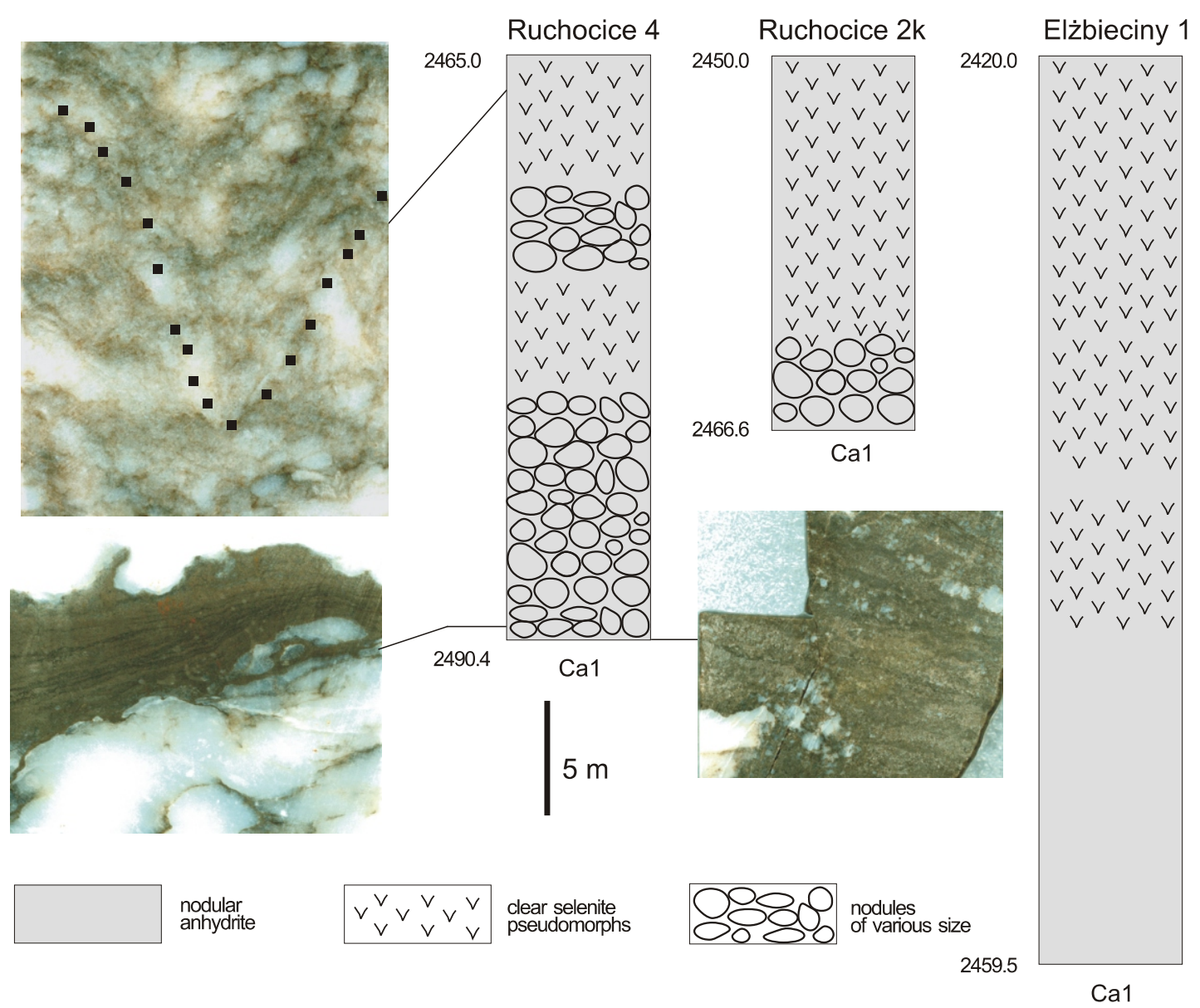

Fig. 7. Cored intervals of the Lower Anhydrite of the Ruchocice 2k, Ruchocice 4 and Elżbieciny 1 boreholes

Outlines of the V-shaped selenitic gypsum pseudomorph in the upper left photo shown by dots 


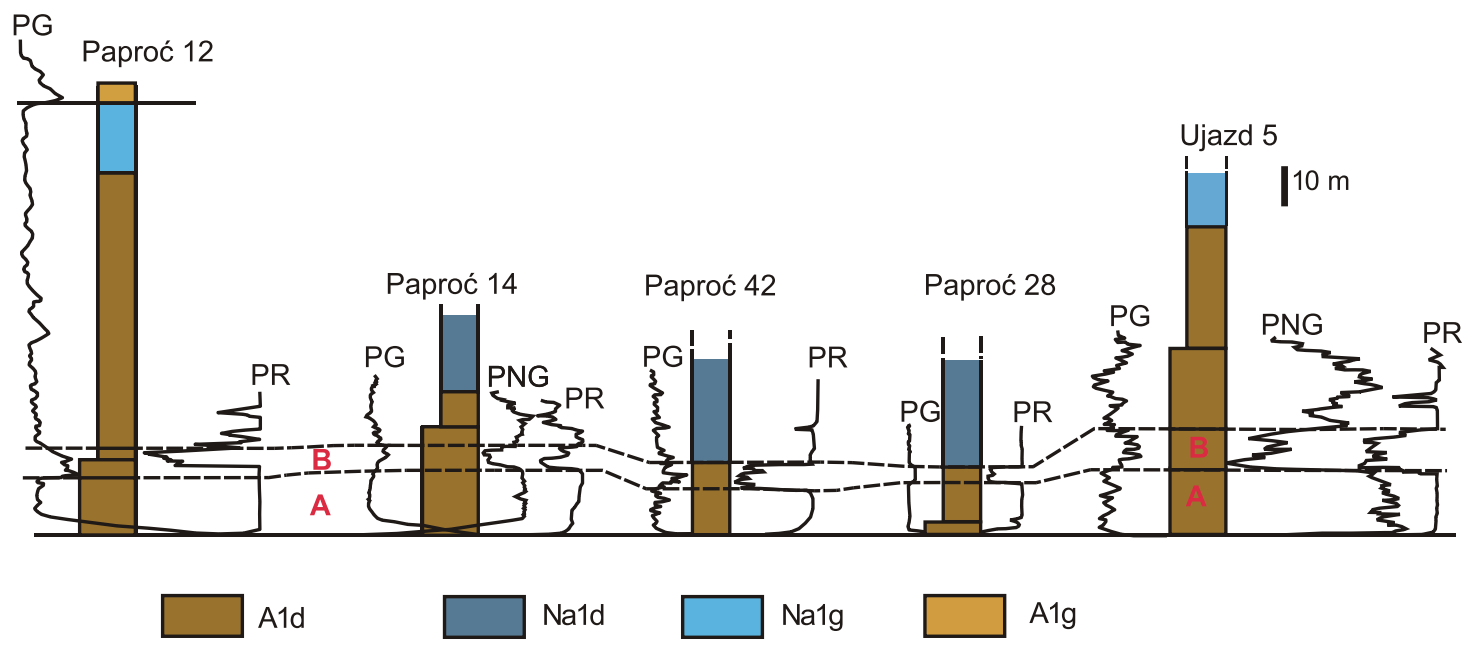

Fig. 8. Geophysical correlation of the Lower Anhydrite units in the Paproć-Ujazd region

PG - gamma log, PNG - neutron-gamma log, PR - resistivity log; the thick column (lower part of Paproć 12, 14 and Ujazd 5) shows the cored interval; the thin column shows lithology according to geophysical logs

A
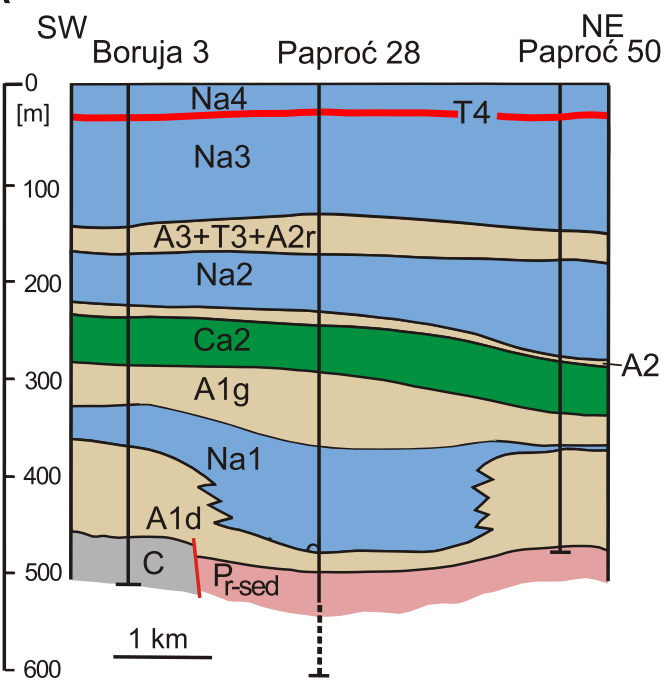

C

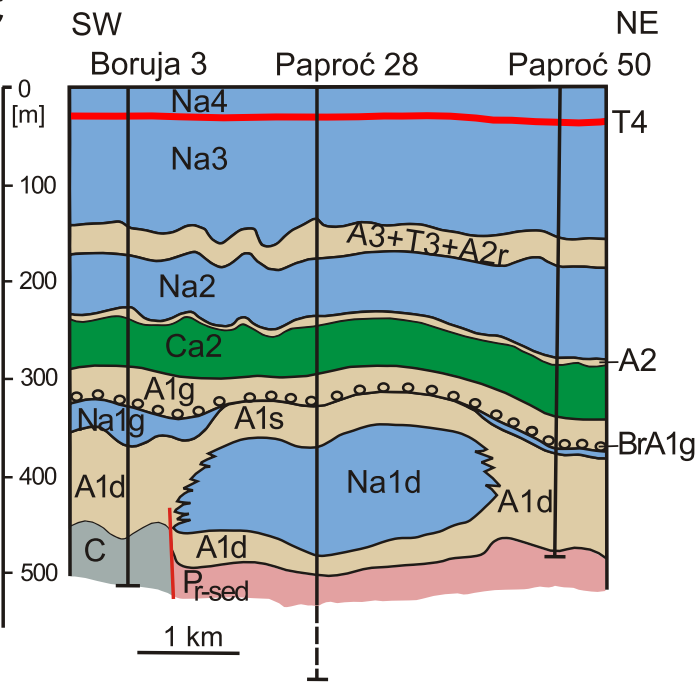

B

SW $\begin{array}{ll}\text { NE } \\ \text { Boruja } 3 & \text { Paproć } 28 \quad \text { Paproć } 50\end{array}$

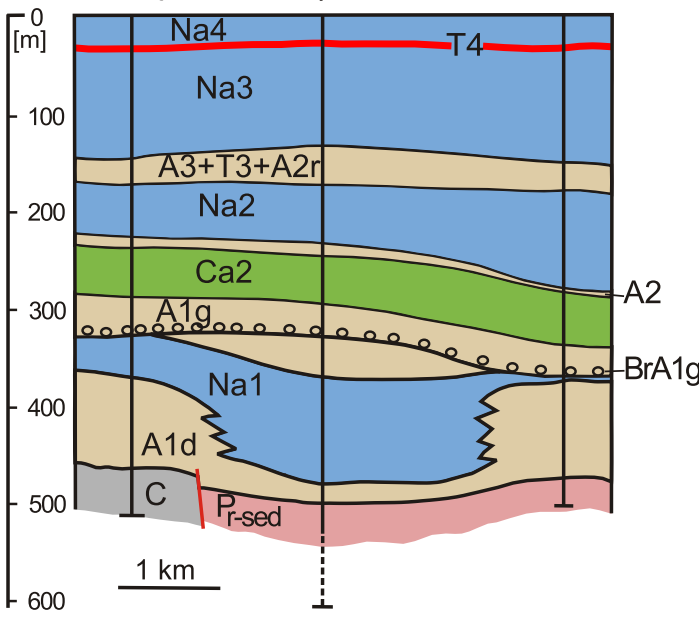

Fig. 9. Interpretative sections along the Boruja 3-Paproć 28-Paproć 50 line

A - conventional, without considering seismic data; B taking into account the occurrence of anhydrite breccias at the base of Upper Anhydrite; $\mathbf{C}$ - with use of seismic data; A1d - Lower Anhydrite, A1g - Upper Anhydrite, A1s - Middle Anhydrite, A2 - Basal Anhydrite, A2r - Screening Anhydrite, A3 - Main Anhydrite, BrA1g - Anhydrite Breccia, C - Carboniferous, Ca1 - Zechstein Limestone, Ca2 - Main Dolomite, Na1 - Oldest Halite, Na1d - Lower Oldest Halite, Na1g - Upper Oldest Halite, Na2 - Older Halite, Na3 - Younger Halite, Na4 - Youngest Halite, $\mathrm{P}_{\mathrm{r} \text {-sed }}$ - sedimentary Rotliegend, $\mathrm{P}_{\mathrm{r} \text {-vol }}$ - volcanic Rotliegend, T3 - Grey Salt Clay, T4 - Red Salt Clay; notice that because of its negligible thickness the Zechstein Limestone is not shown in this figure nor in many seismic sections shown in Figures 10-20 


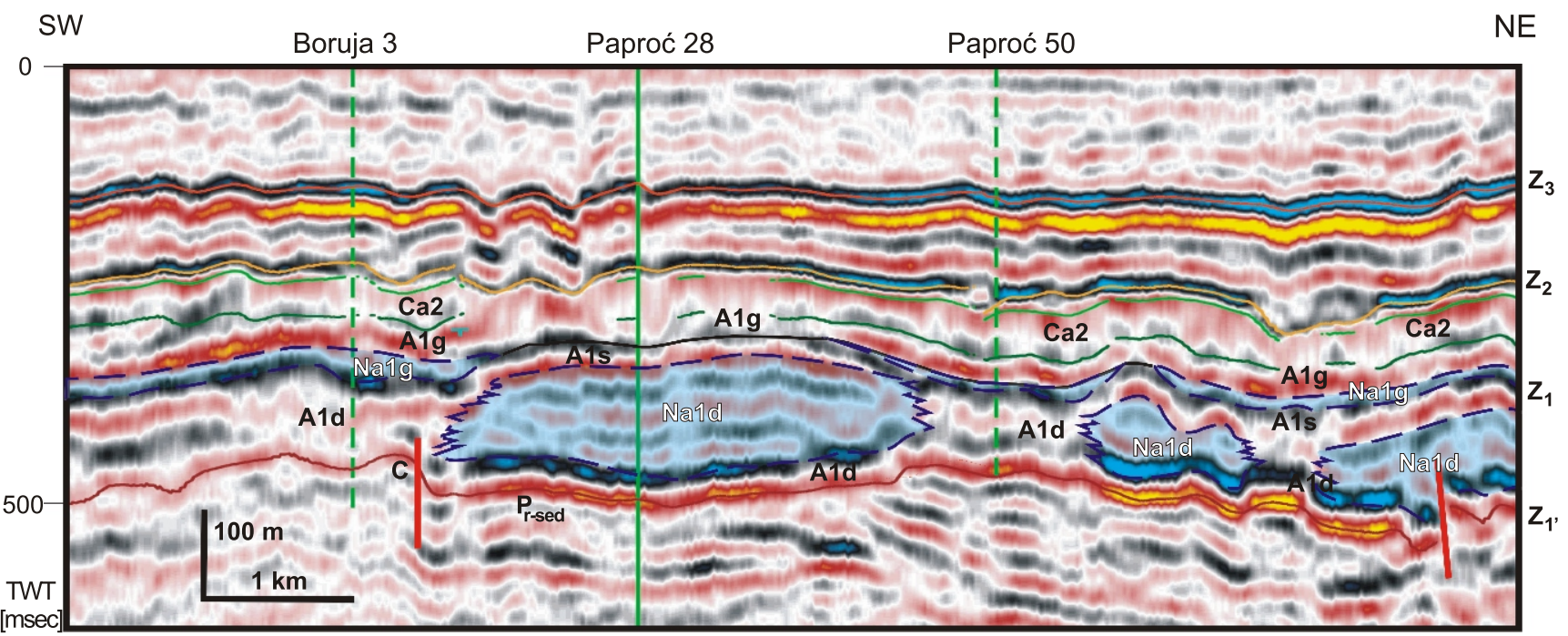

Fig. 10. Seismic section along the Boruja 3-Paproć 28-Paproć 50 line (reference level: Na4 top)

$Z_{1}, Z_{1}, Z_{2}, Z_{3}, Z_{4}$ reflectors: $Z_{4}$ (bottom of $A 4$ or bottom of Na4/top of $A 4$ ), $Z_{3}$ (bottom of Na3/top of $A 3$ ), $Z_{2}$ (bottom of Na2/top of $A 2$ ), $Z_{1}$ (bottom of $\mathrm{Na} 1 /$ top of $A 1 \mathrm{~d}$ ) and $Z_{1}$, (bottom of $A 1 \mathrm{~d}$ or bottom of $\mathrm{Ca} 1 /$ top of $\mathrm{T} 1$ or of the Zechstein substrate;

for other explanations see Figure 9

S

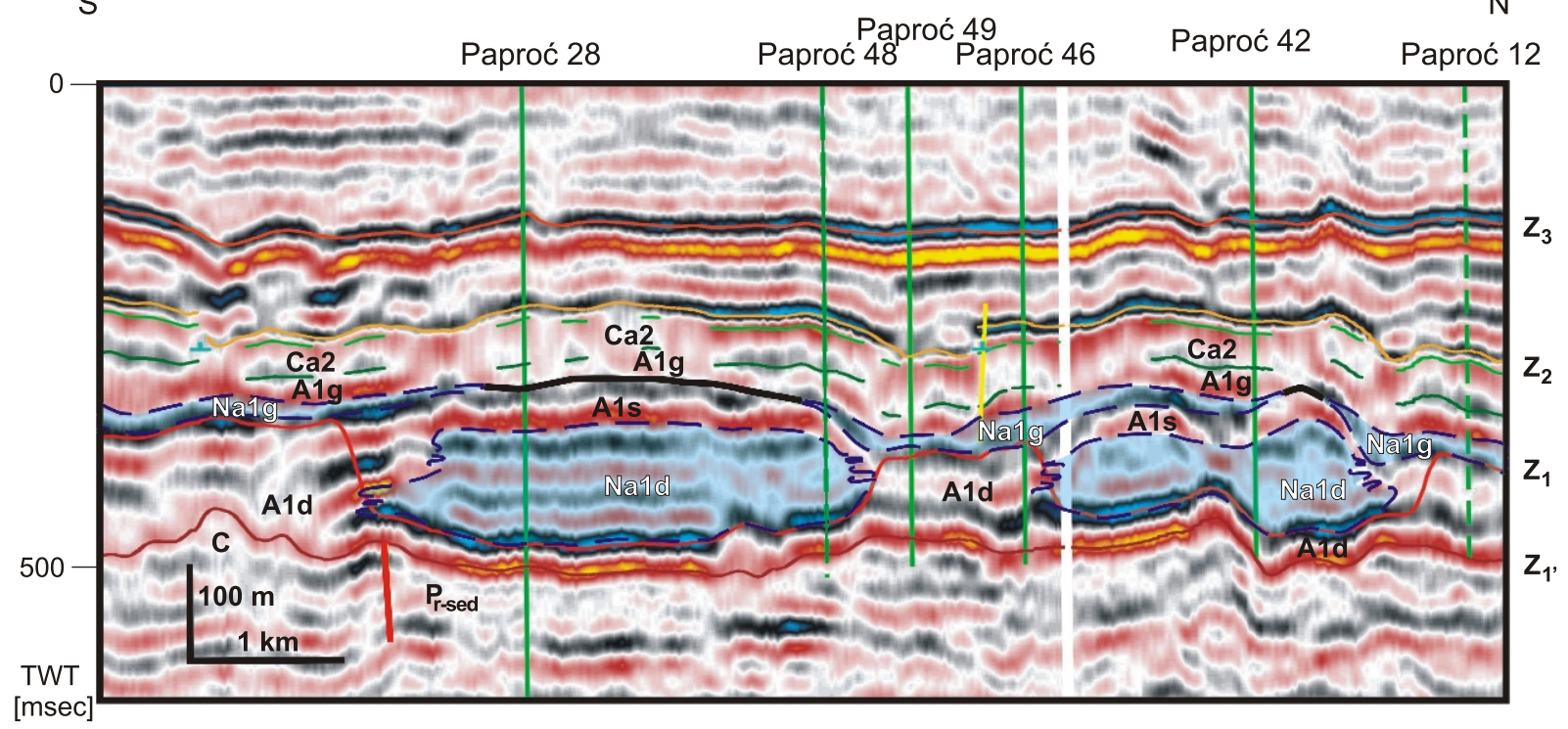

Fig. 11. Seismic section through boreholes Paproć 28, 48, 49, 46, 42, 12 (reference level: Na4 top)

For explanations see Figures 9 and 10

Na1d basin between the Elżbieciny and Ruchocice reefs (cf. Fig. 15). The Elżbieciny reef itself originated at the maximum elevation of the top of the Zechstein substrate (Fig. 15). Figure 18 shows that besides the main Na1d basin there is also a considerably smaller Na1d basin located south of the Ruchocice 4 borehole (Fig. 2). Those two salt basins are separated by a part of the A1d platform located above a $24 \mathrm{~m}$ thick reef limestone in the Ruchocice 4 borehole. In the Ruchocice 4 borehole Na1g is lacking, while this salt unit of very small thickness may probably occur south and north of the borehole; it is easily visible in the Ujazd 5 borehole (23 $\mathrm{m}$ of $\mathrm{Na} 1 \mathrm{~g})$, and poorly visible in the Czarna Wieś 5 borehole (10 m of Na1g; Fig. 18).
Figure 19 shows parts of the main $\mathrm{Na} 1 \mathrm{~d}$ basin separated by a narrow, $600 \mathrm{~m}$ wide A1d platform. Above it and in the adjoining Na1d basins $\mathrm{Na1g}$ is moderately easily visible as documented by the Czarna Wieś $6(14 \mathrm{~m})$ and Zielęcin $1(27 \mathrm{~m})$ boreholes. In the Parzęczewo 2 borehole only $7 \mathrm{~m}$ of this salt and $14 \mathrm{~m}$ of the Middle Anhydrite (A1s) were recorded. Between the Zielęcin 1 and Parzęczewo 2 boreholes its presence is enigmatic as the thickness of a possible salt body is below seismic resolution.

In a part of the seismic section shown in Figure 16 two salt bodies (Na1d and Na1g) identified in the Paproć 4 borehole pass into an anhydrite platform, which is attached to and super- 


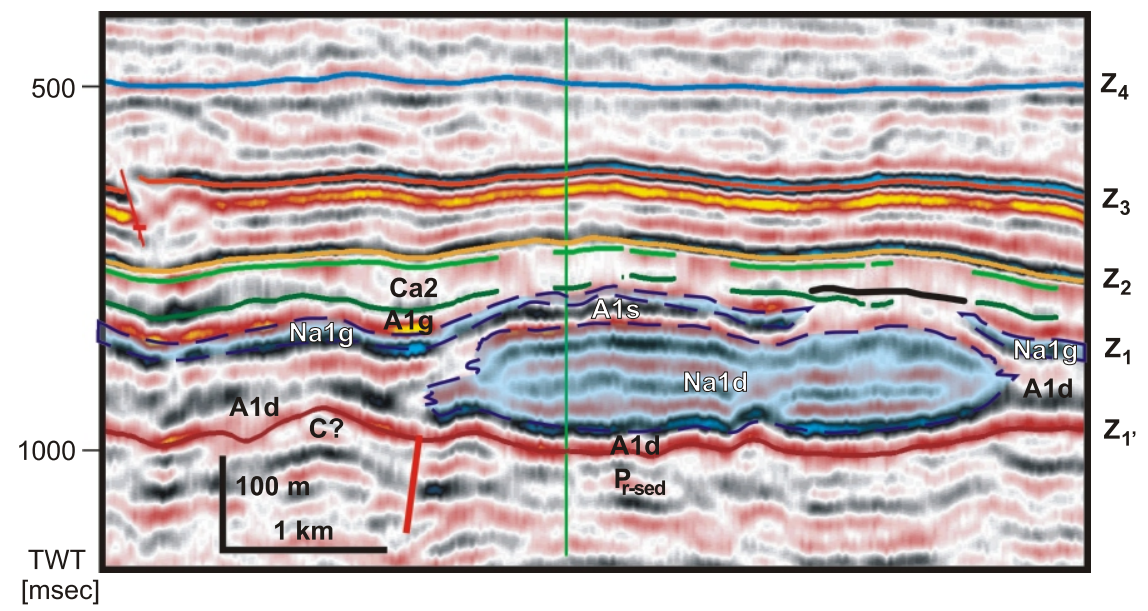

Fig. 12. Seismic section (part of line 750) through the Cicha Góra 5 borehole (reference level: top of Middle Buntsandstein Tp2)

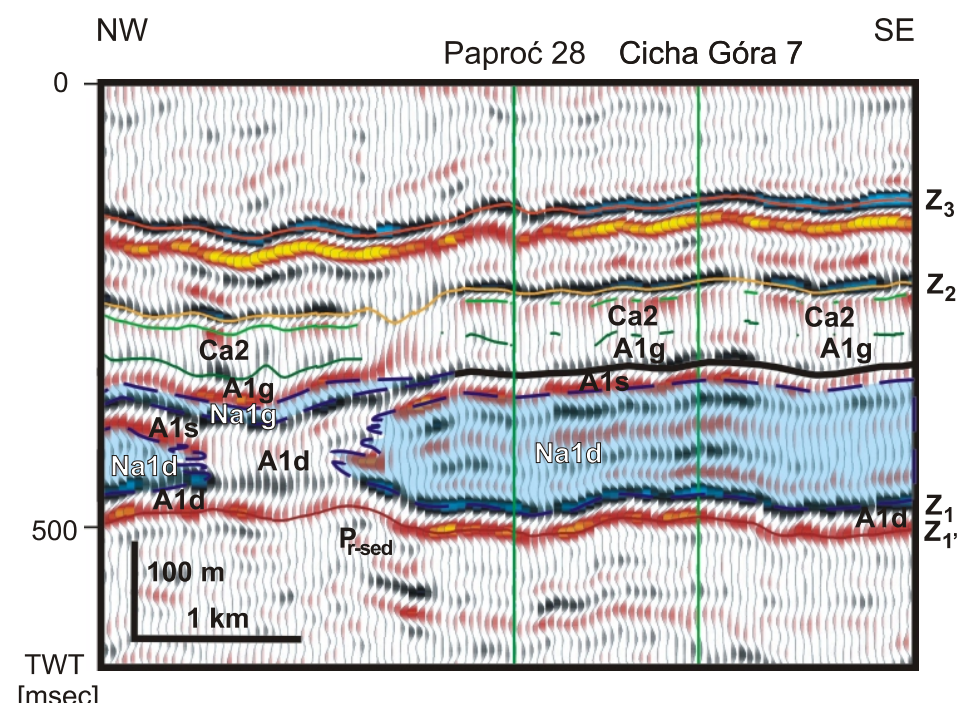

Fig. 13. Seismic section along the Paproć 28-Cicha Góra 7 boreholes (reference level: Na4 top)

For explanations see Figures 9 and 10 imposed on the Nowy Tomyśl and Paproć West reefs. The halite body occurring between those two reefs is interpreted to represent $\mathrm{Na1g}$.

The interpretation of the depositional history of the basal Zechstein deposits along a real section (shown in Figure 14) is given in Figure 22. It is based on the assumption that (1) the relief of the Zechstein sea bottom was varied at the onset of Zechstein deposition (see discussion in Kiersnowski et al., 2010) but it was subject to further differentiation by subtle block tectonics during basal Zechstein deposition; and (2) the depositional surfaces during the termination of halite deposition (i.e., the base of the BrA1g unit) was roughly planar. The interpretation implies that gypsum deposits in the sulphate platform areas underwent multistage dehydration. Previously a very early, almost syndepositional anhydritization of the original gypsum deposit on the platform was inferred for the marginal sulphate platform system in northern Poland (Peryt et al., 1998; cf. Hryniv and Peryt, 2003) as well as in other parts of the Zechstein basin (see Langbein, 1987; Peryt et al., 1993). The preferred occurrence of Na1g deposits on or close to the sulphate platforms strongly suggests that the space in which the deposits of the Na1g could have originated was created due to gypsum dehydration as
$S$

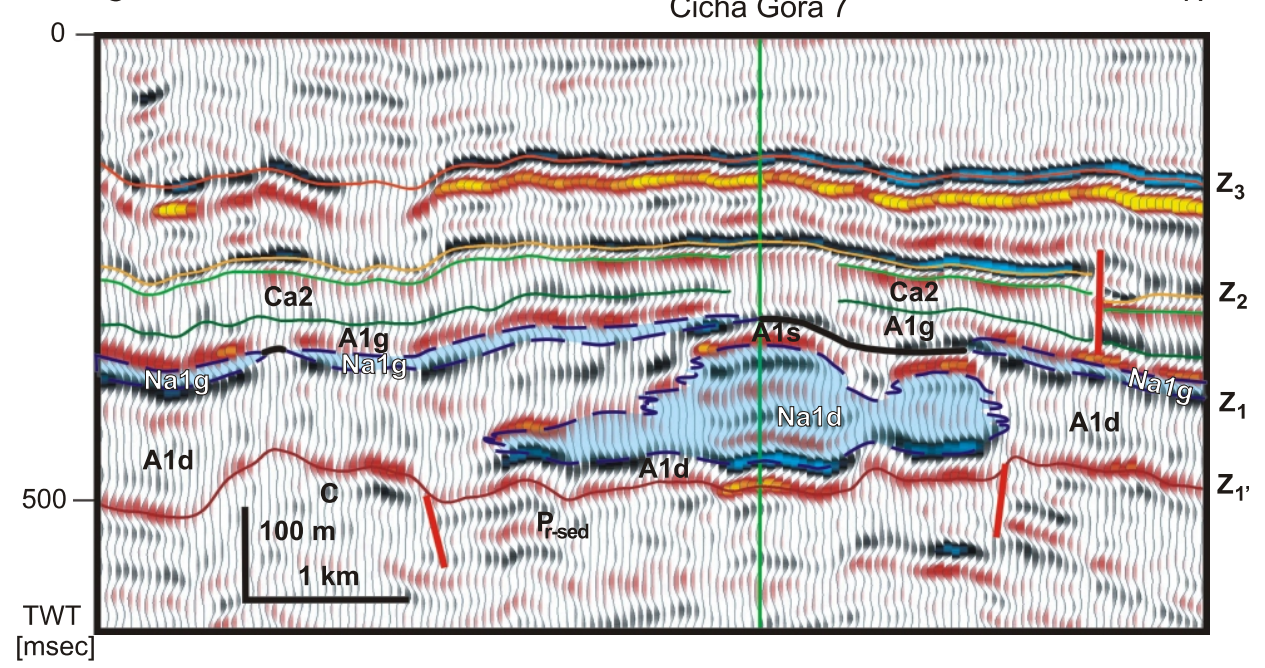

Fig. 14. Seismic section (line 680) through the Cicha Góra 7 borehole (reference level: Na4 top)

For explanations see Figures 9 and 10 


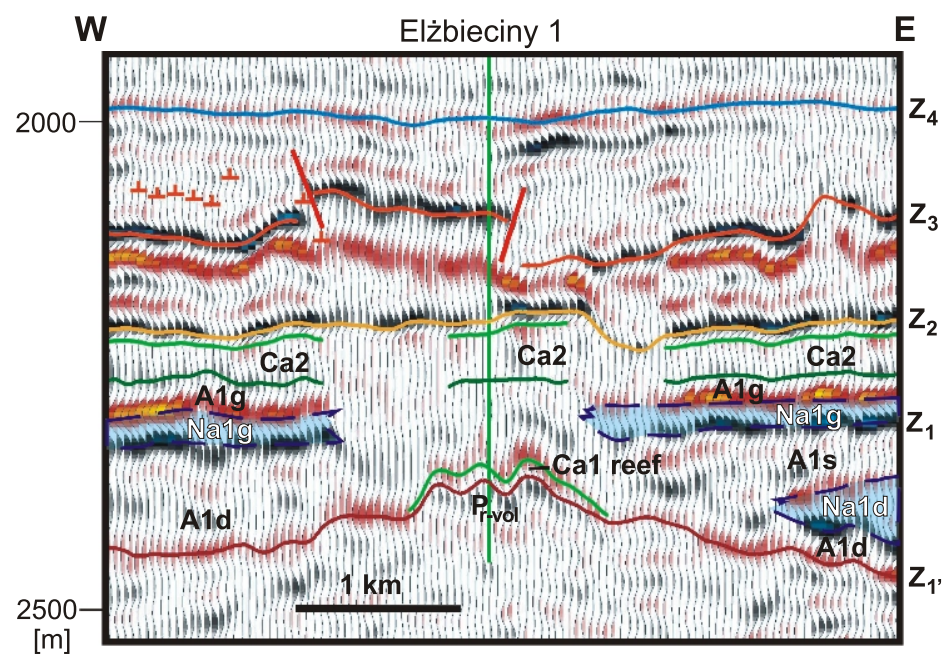

Fig. 15. Depth seismic section through the Elżbieciny 1 borehole (line 540)

The Na1g position of the halite body adjacent to the reef is determined based on geometrical relations; for explanations see Figures 9 and 10 shown in Figure 22. The shift of depocentres outside the $\mathrm{Na1d}$ basin and toward the A1d platforms is a simple consequence of different impact of gypsum dehydration that was controlled by various thickness of gypsum strata related to the sedimentary facies differentiation during later phases of A1d deposition (cf. Peryt, 1994). As shown in Figure 8, the development of the lowest sulphate strata is similar throughout the entire area study.

\section{DISCUSSION}

The PZ1 evaporite basin in the Wolsztyn High area is a classic example of the filling of antecedent topography by halite. Becker and Bechstädt $(2000,2006)$ proposed a self-organization model which combines the shallow-water-shallow-basin and deep-water-deep-basin models of Kendall (1992) in which halite fills newly established basinal relief in the more distal areas. The environmental conditions to be fulfilled for large-scale evaporite precipitation have been discussed by Sonnenfeld (1984) who recapitulated the basic prerequi-

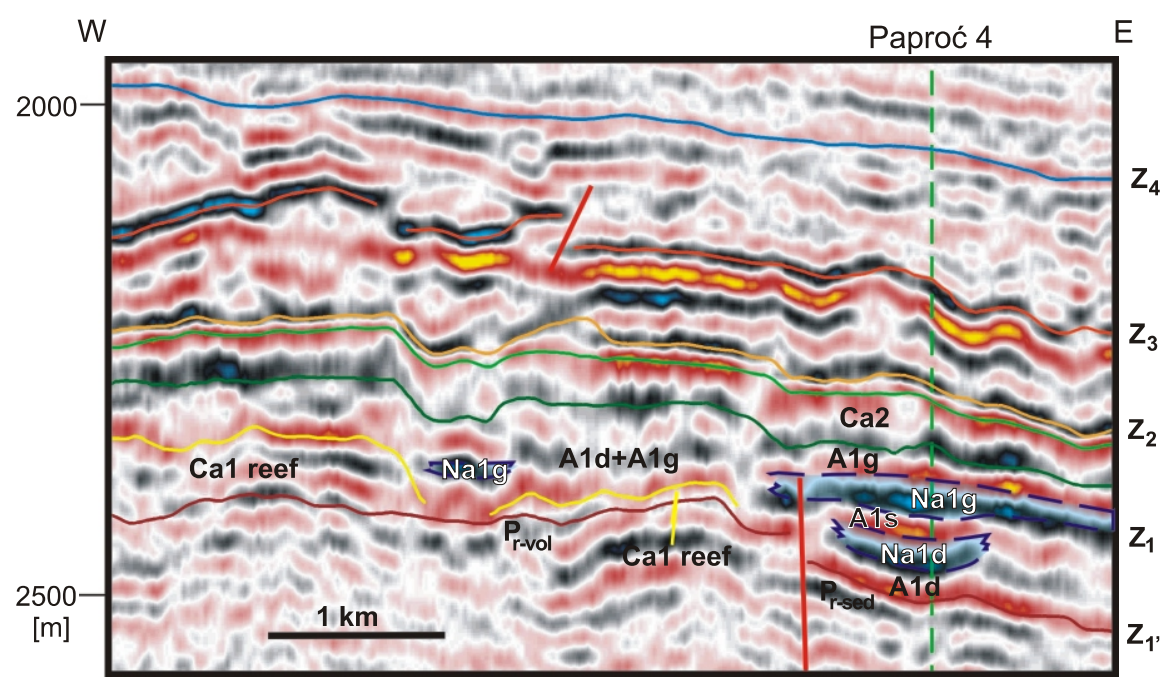

Fig. 16. Seismic section (route 915) through the Paproć 4 borehole

The area of occurrence of halite bodies is controlled by the fault; west of the fault it is not possible to distinguish $\mathrm{A} 1 \mathrm{~d}$ and A1g; the Na1g position of the halite body adjacent to the reef is determined based on geometrical relations; for explanations see Figures 9 and 10

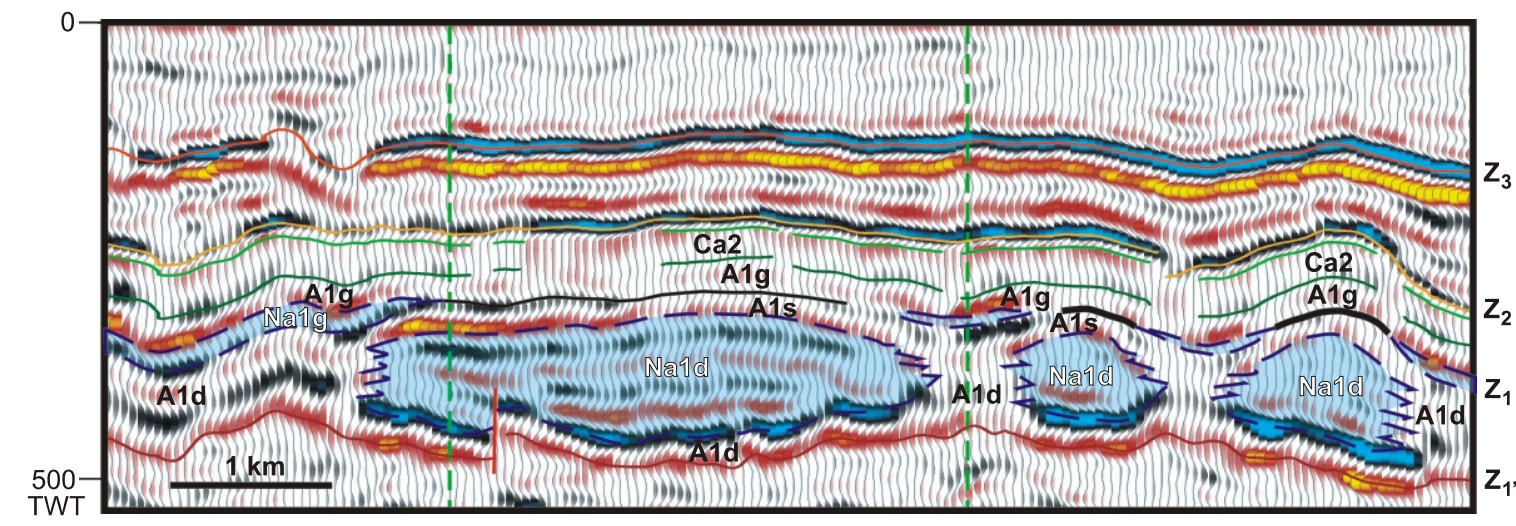

[msec]

Fig. 17. Seismic section through the Cicha Góra 9 and Cicha Góra 1 boreholes (reference level: seismic level $Z_{4}, \mathrm{Na} 4$ top)

For explanations see Figures 9 and 10 


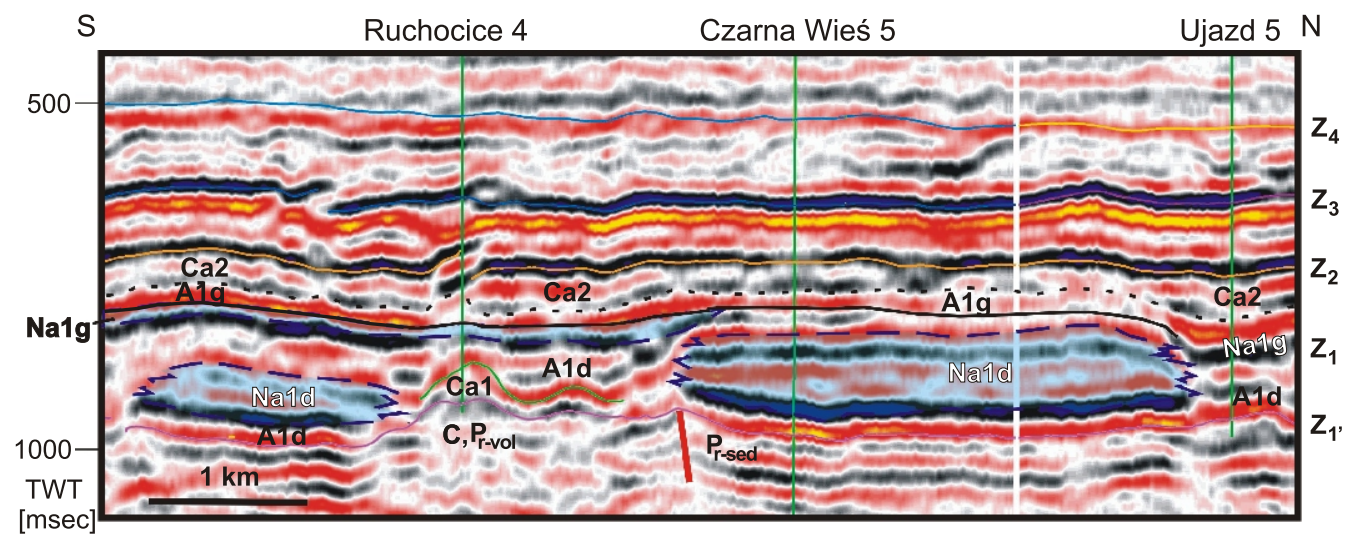

Fig. 18. Seismic section through the Ruchocice 4, Czarna Wieś 5 and Ujazd 5 boreholes (reference level: top of Middle Buntsandstein Tp2)

For explanations see Figures 9 and 10

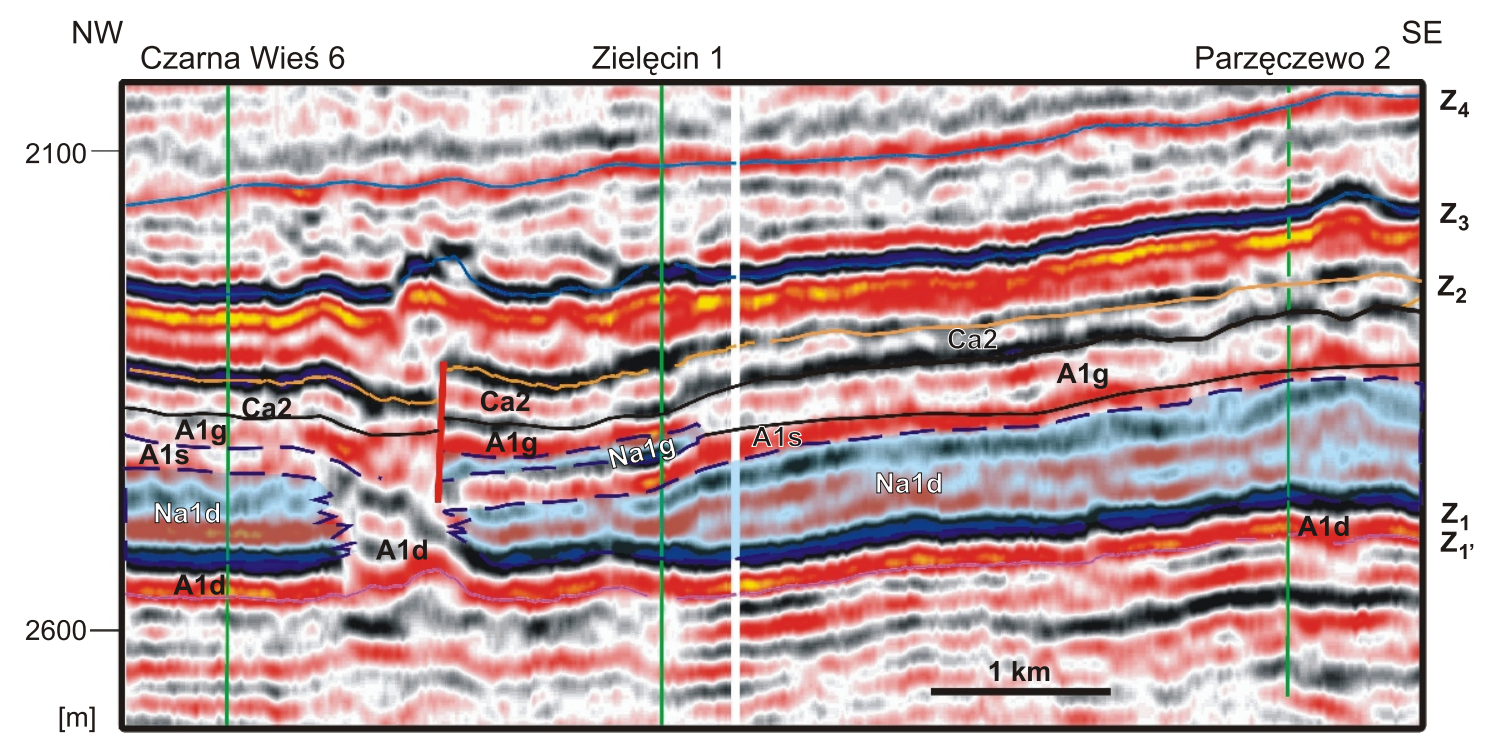

Fig. 19. Depth seismic section through the Czarna Wieś 6, Zielęcin 1 and Parzęczewo 2 boreholes For explanations see Figures 9 and 10

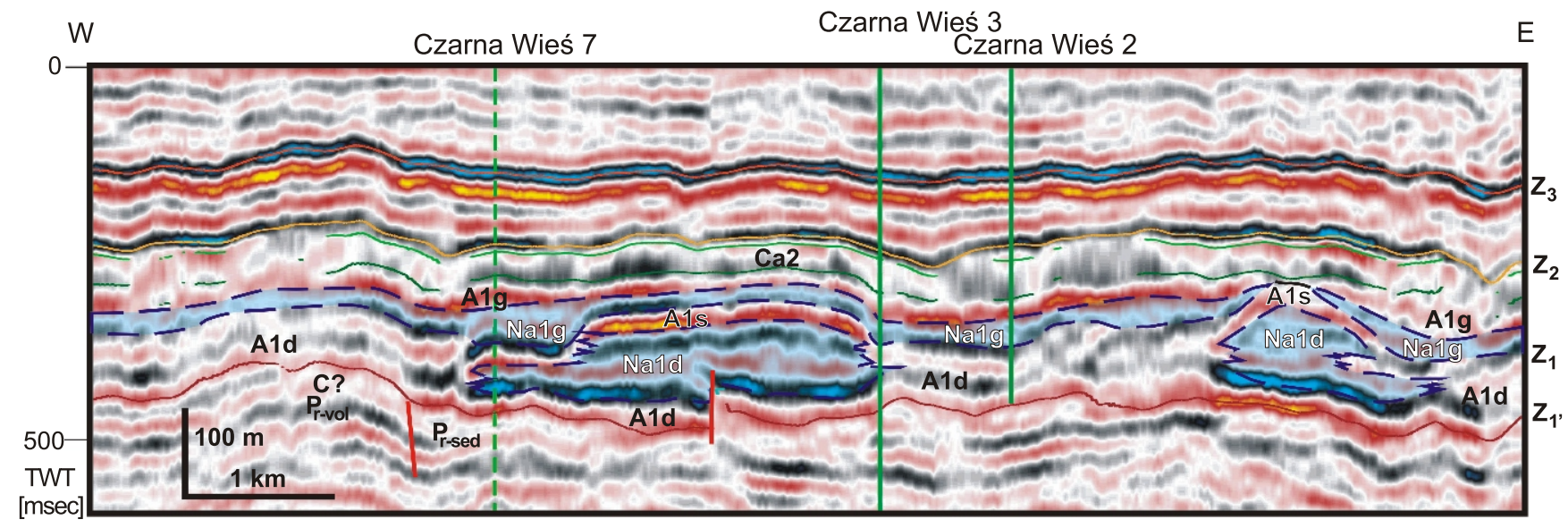

Fig. 20. Seismic section through the Czarna Wieś 7, Czarna Wieś 3 and Czarna Wieś 2 boreholes (reference level: seismic level $Z_{4}, \mathrm{Na} 4$ top)

For explanations see Figures 9 and 10 


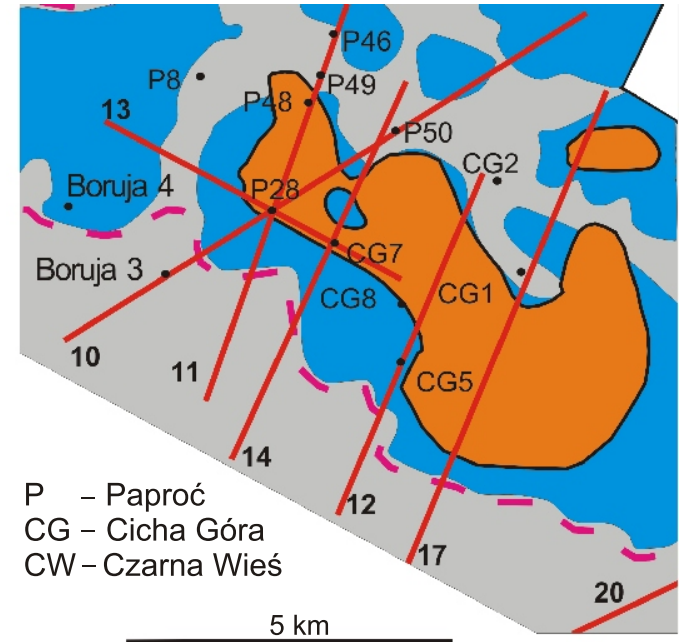

Lower Anhydrite platform deposits

Na1d basin deposits

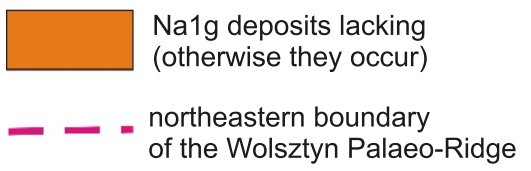

Fig. 21. The Na1d and Na1g basins in the NW part of the study area

sites that must be met. These include: an original depression, a deficit in the water budget, a starved basin, basin shape, an entrance strait, water supply, surface area, brine volume, an adequate time interval, and continued subsidence.

The development of basal Zechstein strata indicates the existence of varied relief after the flooding of the pre-existing depression by the transgressing Zechstein sea (D. Peryt et al., 2012). This relief resulted partly from tectonic rejuvenation during latest Rotliegend and early Zechstein times (see Kiersnowski et al., 2010), and seismic sections clearly show tectonic control via increased subsidence during the deposition of Na1d (e.g., Figs. 16-18).

$\mathrm{T} 1$ is absent over the elevations of the Zechstein substrate, mostly Carboniferous and/or Permian volcanic rocks, where the Ca1 reefs developed. In turn, in the intervening depressions, T1 commonly occurs. $\mathrm{Ca} 1$ is thin and shows a peloidal wackestone to packstone depositional texture with rare to common bioclasts. The restricted fauna, common dwarf foraminifers, with a predominance of lagenids, indicates consistently dysaerobic conditions and possibly elevated salinity in the basin (Peryt et al., 2014).

The Ca1 deposits originated in a deep-water environment and represent a condensation horizon. Across most of the Ca1 basin, including its basinal zone, there are three, or at least two transgressive-regressive cycles (e.g., Peryt, 1984, 1986; Paul, 1986, 2011; Peryt et al., 2010a; Hammes et al., 2013). The lower Zechstein basin in SW Poland was clearly insensitive to fluctuations in sea level recorded elsewhere, presumably because it was too deep. Bio- and magnetostratigraphical data indicate a possible duration of the Zechstein of only 2.8-3.5 Myr (Szurlies, 2013 with references therein; cf. Denison and Peryt, 2009), and Ca1 lasted ca. 0.4 Myr (see Peryt, 1984). Very thin rock units, comparable to those occurring in the Ca1 deposits of the study area, may represent large time spans lasting up to several millions of years, such as in the Jurassic of Spain (Flügel, 2010: p. 214 with references therein). Most of that time is supposed to be hidden within the goethite crusts, hardgrounds and the erosional discontinuities characteristic of most condensed sequences, but lacking in the sections studied. At the top of $\mathrm{Ca} 1$, recrystallised oncoid packstones and other microbially-mediated carbonates occur locally (Peryt et al., 2014) that are reminiscent of much thicker stromatolitic-oncolitic strata. This is characteristic of the topmost part of the basinal Ca1 facies throughout the basin (Smith, 1986 with references therein; Peryt and Peryt, 2012). These strata are considered to have been formed in response to increased salinity during deposition (Smith, 1995; Pope et al., 2000). Eventually, gypsum started to be deposited across the entire study area.

Previous studies indicated that, within the wide belt of the PZ1 evaporite platform system attached to the carbonate platform, during sulphate deposition on local platforms, concurrent chloride deposition occurred in the adjacent basins (e.g., Hollingworth, 1948; Czapowski, 1987; Peryt and Kovalevich, 1996), perhaps due to density stratification of a basin of considerable bathymetry. Those basins followed the pattern inherited after pre-Zechstein sedimentation, although in several cases the seismic sections strongly suggest that variable subsidence during early Zechstein times was related to reactivated faults as shown in seismic sections (Figs. 12, 15-18 and 20) as well as in the reconstruction of depositional history during PZ1 deposition as shown in Figure 22.

This reconstruction assumes that the relief existing at the onset of Zechstein deposition controlled the distribution of the Zechstein Limestone reefs located on the sea-bottom elevations (Dyjaczynski et al., 2001). Subsequently, gypsum platform deposits started to accumulate across the entire area (I in Figure 22). After the deposition of two sulphate units shown in Figure 8 , the deposition of halite began in the depressed, faster subsiding part, fault-bounded blocks (II in Figure 22; see Figs. 10-12, 14, 16, 18 and 20). Minor sedimentary tectonics commonly reported from the basal Zechstein on the marginal anhydrite platforms throughout the entire Zechstein Basin (e.g., Ziegler, 1990; Geluk, 1999) could have had a decisive control on the development, or at least the initiation, of the halite basin (Fig. 22). This subtle tectonic control on evaporite facies distribution is not unique - it is well-demonstrated, for example, in northern Poland (e.g., Peryt, 1994), where the interfingering of gypsum and halite facies during deposition of the PZ1 evaporites was also demonstrated (Peryt and Kovalevich, 1996). This interfingering finds its expression in the borehole cores as alternations of halite and anhydrite.

In time, the area of halite (Na1d) basins decreased, and the place of halite sedimentation was taken by gypsum (III in Figure 22). In general, the marginal evaporite platform system of the Fore-Sudetic area is dominated by anhydrite and intercalations of halite are rare and relatively thin (see Zielińska-Pikulska and Pikulski, 2002, in: Hryniv and Peryt, 2010: fig. 2B).

Then, owing to the volume change related to the phase of gypsum dehydration (albeit the trigger of this remains enigmatic) and related creation of a varied relief (IV in Figure 22), $\mathrm{Na} 1 \mathrm{~g}$ basins could be formed. These are mostly located on and adjacent to the anhydrite platforms as the spatial effect of the gypsum dehydration was the greatest there. Eventually the $\mathrm{Na1g}$ basins were filled ( $\mathrm{V}$ in Figure 22), and the Br1A1g deposits accumulated throughout most of the study area. However, the gypsum dehydration was then not complete and the process impacted also on the sedimentary history of the PZ2 strata. 

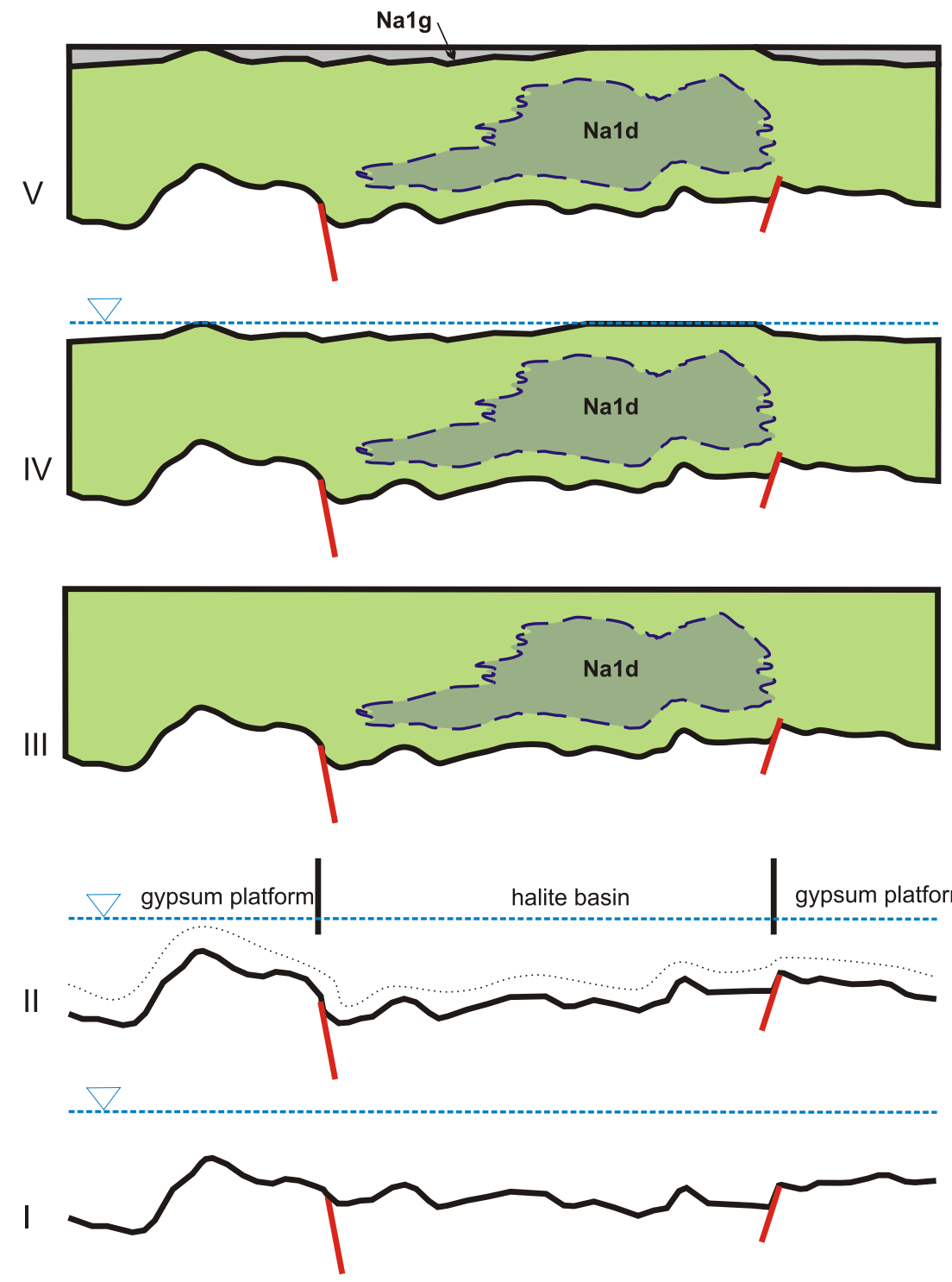

Fig. 22. History of deposition of the basal Zechstein along a real seismic section shown in Figure 14

I - the onset of Zechstein deposition - the depth of water column was several tens to over $100 \mathrm{~m}$ deep (sea level shown by dashed line); II - the deposition of platform gypsum and then, following intensification of fault activity, the development of a halite basin; III - the filling of the PZ1 evaporite basin (A1d-Na1d-A1s interval), the upper surface of evaporite sequence is roughly planar; IV - creation of accommodation space (between the dashed line and the top of the A1d-Na1d-A1s succession) owing to the varied effect of gypsum dehydration (see text for discussion); subsequently, this space was filled by the Na1g deposits - V

Diachroneity of appearance of the chloride facies indicated by correlation of the A1d units (Fig. 8) in various parts of the area studied, suggests that the boundaries between many evaporite units are rarely isochronous. Such a (roughly) isochronous boundary is the base of $\mathrm{A} 1 \mathrm{~d}$ (= the top of Ca1). The unit may be overlain by Na1d (e.g., in Paproć 28 - Fig. 3), Na1g (e.g., in Boruja 3 - Fig. 3) or BrA1g (e.g., in Nowy Tomyśl $2 \mathrm{k})$. The distinction between $\mathrm{Na} 1 \mathrm{~d}$ and $\mathrm{Na} 1 \mathrm{~g}$ is possible when both units occur in a borehole (such as in Cicha Góra 5 - Fig. 3) or owing to correlation of seismic reflectors (e.g., NE of Paproć 50 - Fig. 10). The lower and upper boundaries of Na1d and A1s as well as the lower boundary of $\mathrm{Na} 1 \mathrm{~g}$ are strongly diachronous as they reflect a local, very dynamic system despite the location of the study area in the centre of the basin.

The seismic sections show that the lithological units above the Oldest Halite basins are located distinctly higher than the same units above the A1d platforms. This phenomenon is interpreted as having been related to dehydration of gypsum. The impact of the volume decrease involved (ca. 38\% - see below) was greater in the case of thicker units of mostly selenitic gypsum composing the sulphate platforms, located on the structural highs separating halite basin areas, than in the case of thin 
units of sulphates underlying $\mathrm{A} 1 \mathrm{~d}$. Consequently, owing to the gypsum dehydration, the top surface of the A1d platform has been located considerably lower than the Na1d top in the halite basin, which in general remained in its previous location, and hence the A1d platform areas became the loci where the Na1g deposits could be formed. Considerable deflection of overlying strata - especially clear between two salt basins - could break unit continuity. Such a situation is recorded for example between the Zielęcin 1 and Czarna Wieś 6 boreholes (Fig. 19), and between Paproć 46 and Paproć 49 (Fig. 11). The present location of anhydrite below BrA1g with regard to the platform top also indicates that these deflections are due to gypsum dehydration.

As already mentioned, the anhydrite unit between BrA1g and the Na1d top (e.g., in Paproć 28 - Figs. 3, 10 and 11) or the same unit below Na1g (e.g., in Cicha Góra 5 - Fig. 3) is a lithofacies equivalent of the near-top portion of the A1d platform. This anhydrite unit (so far considered as the lower part of $\mathrm{A} 1 \mathrm{~g}$ or $\mathrm{A} 1 \mathrm{~s}$ ) is bedded (as indicated by dipmeter data in the Paproć 28 borehole collected by Geofizyka Toruń; unpublished documentation of the Paproć 28 borehole) and originated probably due to resedimentation of gypsum from the platform to the basin after the deposition of Na1d. The platform surface had to occur, at that time, higher than the Na1d top in the salt basin and not lower as it is today.

In the study area Na1g often occurs above the structural highs that were shallower areas during the deposition of A1d. The deposition of halite may have led to the elimination of pre-existing relief as precipitation of salts tends to level out any preexisting topography (Sonnenfeld, 1984). Subsequent early, but not syndepositional, dehydration of thicker gypsum formed platforms that were related to the structural highs. These separated individual halite basins (with thin anhydrite units) and produced a new palaeogeographical pattern that was commonly reversed with the previous one. The previous elevations (characterized by selenite gypsum precipitation) became the locations where Na1g salt basins occurred. This effect is due to the volume decrease of gypsum of about ca. $38 \%$ during its dehydration to anhydrite. Rough estimates of the dehydration-induced volume decrease in the sulphate platform areas is $21-32 \%$ and in the halite basin area it is $12-22 \%$ (based on calculations for the section shown in Figure 14).

Preservation of gypsum pseudomorphs observed on the sulphate platform in the study area (e.g., Hryniv and Peryt, 2010; Peryt et al., 2010b; Fig. 7) suggests that the gypsum-anhydrite transition may have been accompanied by influx of sulphate-rich basinal water and precipitation of additional gypsum very early in the depositional history (e.g., Sonnenfeld, 1984; Langbein, 1987). In such a case, a volume change would not be seen. On the other hand, the value derived from the Williston Basin Middle Devonian change in volume associated with the gypsum-anhydrite transition is $37 \pm 4 \%$ (Kindle et al., 1987), the same as the theoretical value. Direct evidences of fluid escape structures produced by fluidization have been observed in the upper part of A1d (Peryt et al., 2010b: p. 390). They are not common because nodular texture (Fig. 7) obliterated many former examples. Therefore, despite uncertainties regarding the mechanisms of anhydritization of gypsum deposits in the study area, the pattern of occurrence of depressions filled by Na1g favours the concept that they were formed shortly after the previous relief was leveled by Na1d deposition. However, the average thickness of $\mathrm{Ca} 2$ that is larger above the $\mathrm{A} 1 \mathrm{~d}$ platforms than above the salt basins in the Paproć-Cicha Góra area (a 5 m-difference between the Paproć 28 and Paproć 50 boreholes: Fig. 9C) strongly suggests that dehydration-related deformations continued after the deposition of A1g. Consequently, the prime controls on the deposition of the PZ1 evaporites in the area studied were:

- bathymetrical differentiation of the sedimentary basin, both inherited and tectonically modified during deposition,

- dehydration of original gypsum deposits, as shown in Figure 22.

There is also no doubt that differential compaction was partly responsible for the origin of the anhydrite platforms, as was indicated by Langbein (1987), and this was closely related to different times of anhydritization in sulphate platforms and adjacent basins.

It was shown previously that gypsum diapirs might form within the $\mathrm{A} 1, \mathrm{~A} 2$ and $\mathrm{A} 3$ units of Germany (Fulda, 1929; Hemmann, 1972; Paul, 1987; Williams-Stroud and Paul, 1997) very early after deposition, and primary sedimentary structures and gypsum pseudomorphs are still recognizable within the diapirs (Williams-Stroud and Paul, 1997); thus the eventual contribution of very early gypsum diapirism in accommodation space and the complicated interbedding of halite and anhydrite should be considered. Hemmann (1972: figs. 14, 15) showed that diapirs in A3 are up to $60 \mathrm{~m}$ high, whereas A3 is only $30 \mathrm{~m}$ thick. Paul (1987) indicated, in A1 in the Harz Mts., very often there is a shear horizon within the gypsum and therefore only the upper part of the gypsum has moved. The diapir can also intrude laterally into weak horizons thus forming the A1s. However, although the possibility that such mechanisms operated in the case of PZ1 cannot be neglected, the relations between particular lithological units observed for example in Figure 14 SWS of the Cicha Góra 7 borehole strongly suggest that they are original, sedimentary transitions. Their current pattern, however, was modified by various timings of anhydrite formation.

In addition, the different rheological properties of halite compared with those of anhydrite could additionally have impacted the original spatial pattern of evaporite occurrence as indicated by an important role played by horizontal or sub-horizontal movements within the Oldest Halite in the southern part of the Fore-Sudetic area (e.g., Markiewicz and Becker, 2009; Toboła, 2014).

\section{CONCLUSIONS}

1. Analysis of sections from a 3D seismic volume calibrated by sedimentological and geophysical logging of basal Zechstein strata in SW Poland shows that instead of three conventionally recognized evaporite units in the PZ1 cycle (lower and upper anhydrite unit, with halite unit between them), five units occur. These are, from the base to the top: A1d (Lower Anhydrite), Na1d (Lower Oldest Halite), A1s (Middle Anhydrite), Na1g (Upper Oldest Halite), and A1g (Upper Anhydrite). The number of these units in various places varies from two (Lower Anhydrite at the base of the PZ1 cycle and Upper Anhydrite at the top of the PZ1 cycle occur at every location) to five (see above).

2. The PZ1 evaporites were deposited in far more complex and dynamic system than assumed previously.

3. The development of basal Zechstein strata was controlled by the existence of a varied relief after the flooding of the pre-existing depression by the transgressing Zechstein Sea. The usually $<1 \mathrm{~m}$ thin, deep-marine Zechstein Limestone car- 
bonates consist of mostly peloidal and bioclastic wackestones and packstones, with some recystallised oncoid packstones and other microbially-mediated carbonates. They show sedimentary condensation manifested by bored and encrusted grains.

4. A geological-geophysical correlation shows that two units of Lower Anhydrite occur throughout the platform and basinal zones showing a deepening-upwards (transgressive) trend. The lower A unit is composed of nodular anhydrite, and the higher B unit contains anhydrite with carbonate laminae, often supposedly of microbial nature. The latter terminates the Lower Anhydrite basinal sections and thus halite sedimentation in the deepest parts of the salt basins began shortly after deposition of the B unit. By contrast, in the Lower Anhydrite platform area sulphate deposition lasted for a long time. The diachroneity of appearance of chloride facies in various parts of the study area suggests that the boundaries between many evaporite units are rarely (roughly) isochronous.

5. Seismic sections show that the Lower Oldest Halite deposits occur in depressions. Between the halite basins, anhydrite platforms of the Lower Anhydrite occur, and the thickness of anhydrite platform deposits is smaller than the thickness of halite basin deposits. The Upper Oldest Halite in turn is recorded above the anhydrite platform and only rarely it occurs in areas where the Lower Oldest Halite occurs. Usually it pinches out towards the central part of the Lower Oldest Halite bodies although in a few cases it occurs above the entire area of the occurrence of the Lower Oldest Halite. The thickness of the Lower Oldest Halite deposits is invariably greater than that of the Upper Oldest Halite.

6. The lithological units above the Lower Oldest Halite basins occur distinctly higher than the same units above the Lower Anhydrite platforms due to the greater impact of gypsum dehydration in the platform than in the basin areas. Accordingly, the areas of previous shallower zones characterized by selenite gypsum precipitation became the loci of Upper Oldest Halite deposition.

7. Although the prime control on the development of the basal Zechstein strata was inherited relief, an additional, important factor influencing the facies arrangement and depositional history was syndepositional subsidence induced either by anhydritization of gypsum (producing accommodation space for the deposition of the Upper Oldest Halite) or by local subsidence due to the reactivation of faults that controlled the spatial deposition of the Lower Oldest Halite.

Acknowledgements. We thank the Polish Oil and Gas Company and Geofizyka Toruń for permission to use rock and seismic material for this study, and K. Chłódek, H. Kiersnowski, K. Kucharczyk, D. Peryt and P. Raczyński for help throughout this study. The research was supported by statutory funds of PGI-NRI (grant No. 61.2901.1301.00.0). Comments from reviewers P. Krzywiec, J. Paul and F. Strozyk helped us to improve the manuscript greatly. We owe special thanks to J. Zalasiewicz for his editorial comments and improvements.

\section{REFERENCES}

Antonowicz, L., Knieszner, L., 1984. Zechstein reefs of the Main Dolomite in Poland and their seismic recognition. Acta Geologica Polonica, 34: 81-94.

Becker, F., Bechstädt, T., 2000. Presaline sedimentation controlling the initial development of a giant salt deposit (Zechstein Cycle-1, Germany). Proceedings of the 8th World Salt Symposium 2000, The Hague, The Netherlands: 77-82.

Becker, F., Bechstädt, T., 2006. Sequence stratigraphy of a carbonate-evaporite succession (Zechstein 1, Hessian Basin, Germany). Sedimentology, 53: 1083-1120.

Czapowski, G., 1987. Sedimentary facies in the Oldest Rock Salt (Na1) of the Łeba elevation (northern Poland). Lecture Notes in Earth Sciences, 10: 207-224.

Denison, R.E., Peryt, T.M., 2009. Strontium isotopes in the Zechstein anhydrites of Poland: evidence of varied meteoric contributions to marine brines. Geological Quarterly, 53 (2): 159-166.

Dyjaczynski, K., Górski, M., Mamczur, S., Peryt, T.M., 2001. Reefs in the basinal facies of the Zechstein Limestone (Upper Permian) of Western Poland. Journal of Petroleum Geology, 24: 265-285.

Flügel, E., 1982. Microfacies Analysis of Limestones. Springer, Berlin.

Flügel, E., 2010. Microfacies of Carbonate Rocks. Analysis, Interpretation and Application. Springer, Heidelberg.

Fulda, E., 1929. Über "Anhydrit-Klippen”. Kali, 23: 129-133.

Gast, R.E., 1988. Rifting im Rotliegenden Niedersachsens. Geowissenschaften, 4: 115-122.

Geluk, M., 1999. Late Permian (Zechstein) rifting in the Netherlands: models and implications for petroleum geology. Petroleum Geoscience, 5: 189-199.
Górski, M., Gierszewska, D., Król, E., Urbańska, H., Wilk, W. 2000. Lithofacies interpretation of 3D seismic data: key to success in the Zechstein Limestone reef detection in the Permian Basin (on example of the Kościan Reef - western Poland) (in Polish with English summary). Przegląd Geologiczny, 48: 137-150.

Hammes, U., Krause, M., Mutti, M., 2013. Unconventional reservoir potential of the upper Permian Zechstein Group: a slope to basin sequence stratigraphic and sedimentological evaluation of carbonates and organic-rich mudrocks, Northern Germany. Environmental Earth Sciences, 70: 3797-3816.

Hemmann, M., 1972. Ausbuildung und Genese des Leinesteinsalzes und des Hauptanhydrits (Zechstein 3) im Ostteil des Subherzynen Beckens. Berichte der Deutsche Gesellschaft für Geologische Wissenchaften, B16: 307-411.

Hollingworth, S.E., 1948. Evaporites. Proceedings of Yorkshire Geological Society, 27: 192-298.

Hryniv, S.P., Peryt, T.M., 2003. Sulfate cavity filling in the Lower Werra Anhydrite (Zechstein, Poland), Zdrada area, northern Poland: evidence for early diagenetic evaporite paleokarst formed under sedimentary cover. Journal of Sedimentary Research, 73: 451-461.

Hryniv, S., Peryt, T.M., 2010. Strontium distribution and celestite occurrence in Zechstein (Upper Permian) anhydrites of West Poland. Chemie der Erde, 70: 137-147.

Kendall, A.C., 1992. Evaporites. In: Facies Models - Response to Sea Level Change (eds. R.G. Walker and N.P. James): 375-409. Geological Association of Canada, St. Johns.

Kendall, A.C., 2010. Marine evaporites. GeoText, 6: 503-537.

Kiersnowski, H., Peryt, T.M., Buniak, A., Mikołajewski, Z., 2010. From the intra-desert ridges to the marine carbonate island 
chain: middle to late Permian (Upper Rotliegend-Lower Zechstein) of the Wolsztyn-Pogorzela high, west Poland. Geological Journal, 44: 319-335.

Kindle, C., Roark, L., Jordan, T.E., 1987. A stratigraphic test of gypsum dehydration and implications for basin development. Fifth International Williston Basin Symposium.

Kłapciński, J., 1966. Stratigraphy of the Werra-Anhydrites in the region of Lubin and Sieroszowice (in Polish with English summary). Rocznik Polskiego Towarzystwa Geologicznego, 36: 65-78.

Kotarba, M.J., Peryt, T.M., Kosakowski, P., Więcław, D., 2006. Organic geochemistry, depositional history and hydrocarbon generation modelling of the Upper Permian Kupferschiefer and Zechstein Limestone strata in south-west Poland. Marine and Petroleum Geology, 23: 371-386.

Langbein, R., 1987. The Zechstein sulphates: the state of the art. Lecture Notes in Earth Sciences, 10: 143-188.

Lorenc, S., 1975. Petrography and facies differentiation in the Werra limestones and anhydrite rocks, Fore-Sudetic Monocline, SW Poland (in Polish with English summary). Geologia Sudetica, 10: 59-104.

Markiewicz, A., Becker, R., 2009. The original extent of the Oldest Halite (Na1) in the southern part of the Fore-Sudetic Monocline (SW Poland). Geologia, 35: 327-348.

Ortí, F., 2010. Selenite facies in marine evaporites: a review. IAS Special Publication, 43: 431-464.

Ortí Cabo, F., Pueyo, Mur, J.J., Geisler-Cussey, D., Dulau, N. 1984. Evaporitic sedimentation in the coastal salinas of Santa Pola (Alicante, Spain). Revista d'Investigacions Geologiques, 38/39: 169-220.

Oszczepalski, S., Rydzewski, A., 1987. Paleogeography and sedimentary model of the Kupferschiefer in Poland. Lecture Notes in Earth Sciences, 10: 189-205.

Paul, J., 1986. Stratigraphy of the Lower Werra Cycle (Z1) in West Germany (preliminary results). Geological Society Special Publications, 22: 149-156.

Paul, J., 1987. Der Zechstein am Harzrand: Querprofil über eine permische Schwelle. In: Zechstein 87 (eds. J. Kulick and J. Paul). Internationales Symposium. Exkursionsführer, 2: 193-276, Wiesbaden.

Paul, J., 2011. Zum Alter der Korbacher Spalte und dem Klima des Zechsteins (Hessen, Werra-Formation). Geologisches Jahrbuch Hessen, 137: 103-110.

Peryt, D., Peryt, T.M., Raczyński, P., Chłódek, K., 2012. Foraminiferal colonization related to the Zechstein (Lopingian) transgression in the western part of the Wolsztyn Palaeo-Ridge area, Western Poland. Geological Quarterly, 56 (3): 529-546.

Peryt, T.M., 1984. Sedimentation and early diagenesis of the Zechstein Limestone in Western Poland (in Polish with English summary). Prace Instytutu Geologicznego, 109: 1-70.

Peryt, T.M., 1986. Chronostratigraphical and lithostratigraphical correlations of the Zechstein Limestone of Central Europe. Geological Society Special Publications, 22: 201-207.

Peryt, T.M., 1994. The anatomy of a sulphate platform and adjacent basin system in the Łeba sub-basin of the Lower Werra Anhydrite (Zechstein, Upper Permian), northern Poland. Sedimentology, 41: 83-113.

Peryt, T.M., 2010. Zechstein 1-3 evaporites of the Gorzów Block (NW Poland) (in Polish with English summary). Przegląd Geologiczny, 58: 689-694.

Peryt, T.M., Kovalevich, V.M., 1996. Origin of anhydrite pseudomorphs after gypsum crystals in the Oldest Halite (Werra, Upper Permian, northern Poland). Zentralblatt für Geologie und Paläontologie, I: 337-356.

Peryt, T.M., Peryt, D., 2012. Foraminiferal and geochemical records of environmental changes during Zechstein Limestone (Lopingian) deposition in Northern Poland. Geological Quarterly, 56 (1): 187-198.
Peryt, T.M., Ważny, H., 1980. Microfacies and geochemical development of the basin facies of the Zechstein Limestone (Ca1) in western Poland. Contributions to Sedimentology, 9: 279-306.

Peryt, T.M., Orti F., Rosell, L., 1993. Sulfate platform-basin transition of the Lower Werra Anhydrite (Zechstein, Upper Permian), SW Poland: facies and petrography. Journal of Sedimentary Petrology, 63: 646-658.

Peryt, T.M., Kasprzyk, A., Antonowicz, L., 1996. Upper Werra Anhydrite (Zechstein, Upper Permian) in Poland. Bulletin of the Polish Academy of Sciences, Earth Sciences, 44: 121-130.

Peryt, T.M., Pierre, C., Gryniv, S.P., 1998. Origin of polyhalite deposits in the Zechstein (Upper Permian) Zdrada Platform (northern Poland). Sedimentology, 45: 565-578.

Peryt, T.M., Geluk, M.C., Mathiesen, A., Paul, J., Smith, K. 2010a. Zechstein. In: Petroleum Geological Atlas of the Southern Permian Basin Area (eds. J.C. Doornenbal and A.G. Stevenson): 123-147. EAGE Publications, b.v. (Houten).

Peryt, T.M., Hałas, S., Hryniv, S.P., 2010b. Sulphur and oxygen isotope signatures of Late Permian Zechstein anhydrites, West Poland: seawater evolution and diagenetic constraints. Geological Quarterly, 54 (4): 387-400.

Peryt, T.M., Durakiewicz, T., Kotarba, M.J., Oszczepalski, S., Peryt D., 2012a. Carbon isotope stratigraphy of the basal Zechstein (Lopingian) strata in Northern Poland. Geological Quarterly, 56 (2): 285-298

Peryt, T.M., Raczyński, P., Peryt, D., Chłódek, K., 2012b. Upper Permian reef complex in the basinal facies of the Zechstein Limestone (Ca1), western Poland. Geological Journal, 46: $537-552$.

Peryt, T.M., Hałas, S., Peryt, D., 2014. Carbon and oxygen isotopic composition and foraminifera of condensed basal Zechstein (Upper Permian) strata in western Poland: environmental and stratigraphic implications. Geological Journal, DOI: 10.1002/gj.2549

Pharaoh, T.C., Dusar, M., Geluk, M., Kockel, F., Krawczyk, C., Krzywiec, P., Scheck-Wenderoth, M., Thybo, H., Vejbaek, O., Wees, J.-D. van, 2010. Tectonic evolution. In: Petroleum Geological Atlas of the Southern Permian Basin (eds. J.C. Doornenbal and A.G. Stevenson): 25-58. EAGE (Houten).

Podemski, M., 1973. The Zechstein sedimentation in the western part of the Fore-Sudetic Monocline in the vicinity of Nowa Sól (in Polish with English summary). Prace Instytutu Geologicznego, 71: 1-101.

Pope, M.C., Grotzinger, J.P., Schreiber, B.C., 2000. Evaporitic subtidal stromatolites produced by in situ precipitation: Textures, facies associations, and temporal significance. Journal of Sedimentary Research, 70: 1139-1151.

Richter-Bernburg, G., 1955 . Über salinare Sedimentation. Zeitschrift der deutschen geologischen Gesellschaft, 105: 593-645.

Richter-Bernburg, G., 1985. Zechstein-Anhydrite. Fazies und Genese. Geologisches Jahrbuch, A85: 1-82.

Rockel, W., Ziegenhardt, W., 1979. Strukturelle Kriterien der Lagunenbildung im tieferen Zechstein im Raum südlich Berlin. Zeitschrift für Geologische Wissenschaften, 7: 847-860.

Smith, D.B., 1979. Rapid marine transgressions and regressions of the Upper Permian Zechstein Sea. Journal of Geological Society, 136: 155-156.

Smith, D.B., 1986. The Trow Point Bed - a deposit of Upper Permian marine oncoids, peloids and columnar stromatolites in the Zechstein of NE England. Geological Society Special Publications, 22: 113-125.

Smith, D.B., 1995. Marine Permian in England. Chapman and Hall: London.

Sonnenfeld, P., 1984. Brines and Evaporites. Academic Press, Orlando.

Strohmenger, C., Voigt, E., Zimdars, J., 1996. Sequence stratigraphy and cyclic development of basal Zechstein carbonateevaporite deposits with emphasis on Zechstein 2 off-platform 
carbonates (upper Permian, northeast Germany). Sedimentary Geology, 102: 33-54.

Szurlies, M., 2013. Late Permian (Zechstein) magnetostratigraphy in Western and Central Europe. Geological Society Special Publications, 376: 73-85.

Toboła, T., 2014. Influence of tectonics on petrological characteristics of the anhydrite and anhydrite-halite intercalations in the Oldest Halite (Na1) (Zechstein, Upper Permian) of the Bądzów area (SW Poland). Geological Quarterly, 58 (3): 521-532.

Tomaszewski, J.B., 1962. Zechstein salt deposits of Fore-Sudetic Monocline in the Lubin-Sieroszowice region (in Polish with English summary). Przegląd Geologiczny, 10: 668-671.

Underhill, J.R., Hunter, K.L., 2008. Effect of Zechstein Supergroup (Z1 cycle) Werrahalit pods on prospectivity in the southern North Sea. AAPG Bulletin, 92: 827-851.

Wagner, R., 1994. Stratigraphy and evolution of the Zechstein basin in the Polish Lowland (in Polish with English summary). Prace Państwowego Instytutu Geologicznego, 146: 1-71.
Wagner, R., Peryt, T.M., 1997. Possibility of sequence stratigraphic subdivision of the Zechstein in the Polish Basin. Geological Quarterly, 41 (4): 457-474.

Wagner, R., Piątkowski, T.S., Peryt, T.M., 1978. Polish Zechstein Basin (in Polish with English summary). Przegląd Geologiczny, 26: 673-686.

Warren, J.K., 1982. The hydrological setting, occurrence and significance of gypsum in late Quaternary salt lakes in South Australia. Sedimentology, 29: 609-637.

Warren, J., 1999. Evaporites. Their Evolution and Economics. Blackwell Science, Oxford.

Williams-Stroud, S.C., Paul, J., 1997. Initiation and growth of gypsum piercement structures in the Zechstein Basin. Journal of Structural Geology, 19: 897-907.

Ziegler, P.A., 1990. Geological Atlas of Western and Central Europe. Shell International Petroleum Maatschappij B.V. The Hague. 